\title{
CAMA
}

Centre for Applied Macroeconomic Analysis

\section{Deep Habits and Exchange Rate Pass-through}

\section{CAMA Working Paper 17/2016 April 2016}

\section{Punnoose Jacob}

Reserve Bank of New Zealand and

Centre for Applied Macroeconomic Analysis, ANU

\section{Lenno Uusküla}

Bank of Estonia

\section{Abstract}

Habit persistence at the level of individual goods varieties can explain incomplete exchange rate pass-through to international prices. Deep habits give rise to a dynamic import demand function that leads to import price markup adjustments, independently of nominal pricing frictions. Augmenting a standard New Keynesian two-country model with deep habits, we obtain low exchange rate pass-through to import prices even when local currency prices are relatively flexible. As prices become more rigid, the presence of deep habits further reduces the pass-through of exchange rate fluctuations. Without deep habits, the model requires implausibly high degrees of price stickiness to match the pass-through dynamics triggered by an exchange rate shock in a vector autoregression. 


\section{Keywords}

Exchange Rate Pass-through, Deep Habits, Sticky Prices, Price Markups, Local Currency Pricing

\section{JEL Classification}

F41, E31

\section{Address for correspondence:}

(E) cama.admin@anu.edu.au

ISSN 2206-0332

The Centre for Applied Macroeconomic Analysis in the Crawford School of Public Policy has been established to build strong links between professional macroeconomists. It provides a forum for quality macroeconomic research and discussion of policy issues between academia, government and the private sector.

The Crawford School of Public Policy is the Australian National University's public policy school, serving and influencing Australia, Asia and the Pacific through advanced policy research, graduate and executive education, and policy impact. 


\title{
Deep Habits and Exchange Rate Pass-through *
}

\author{
Punnoose Jacob ${ }^{1}$ and Lenno Uusküla ${ }^{2}$ \\ ${ }^{1}$ Reserve Bank of New Zealand and Centre for Applied Macroeconomic Analysis - Australian National University. \\ ${ }^{2}$ Bank of Estonia
}

April 12, 2016

\begin{abstract}
Habit persistence at the level of individual goods varieties can explain incomplete exchange rate pass-through to international prices. Deep habits give rise to a dynamic import demand function that leads to import price markup adjustments, independently of nominal pricing frictions. Augmenting a standard New Keynesian two-country model with deep habits, we obtain low exchange rate pass-through to import prices even when local currency prices are relatively flexible. As prices become more rigid, the presence of deep habits further reduces the passthrough of exchange rate fluctuations. Without deep habits, the model requires implausibly high degrees of price stickiness to match the pass-through dynamics triggered by an exchange rate shock in a vector autoregression.
\end{abstract}

JEL classification: F41, E31

Keywords: Exchange Rate Pass-through, Deep Habits, Sticky Prices, Price Markups, Local Currency Pricing

*Jacob: Punnoose.Jacob@rbnz.govt.nz. Uusküla: Lenno.Uuskyla@eestipank.ee. The views expressed are those of the authors, and do not necessarily represent the official views of the Reserve Bank of New Zealand, the Bank of Estonia or the Eurosystem. We thank Drago Bergholt, Scott Davis, Francesco Furlanetto, James Graham, Gunes Kamber, Thomas Lubik, Nick Sander, Karsten Staehr, Christoph Thoenissen, Fang Yao, James Yetman, Benjamin Wong, and conference participants at the American Economic Association Meeting 2016, for helpful suggestions. Martin Lumiste provided excellent research assistance. 


\section{Introduction}

The coexistence of highly volatile exchange rates and import prices that are quite stable in local currency, has intrigued international macroeconomists for long. ${ }^{1}$ Incomplete exchange rate passthrough to the prices of internationally traded goods and the ensuing deviations from the law of one price have important implications for consumer welfare and the design of monetary policy (Monacelli, 2005). The workhorse open-economy dynamic stochastic general equilibrium (DSGE) model has mainly appealed to nominal price rigidities in local currency to replicate the incomplete exchange rate pass-through observed in the data (see e.g. Jacob and Peersman, 2013, Rabanal and Tuesta, 2010 and Devereux and Yetman, 2010). However, econometric evidence presented in Gopinath, Itskhoki, and Rigobon (2010) suggests that exchange rate pass-through to local currency import prices is low even conditional on a price change by the importing firm. The sources of incomplete exchange rate pass-through appear to lie beyond nominal pricing frictions.

This paper brings to the fore, the interplay between a real rigidity - deep or good-specific habit persistence - and nominal local currency price stickiness in weakening exchange rate passthrough in an otherwise standard New Keynesian two-country economy. Crucially, deep habits can explain incomplete pass-through in conditions where nominal pricing frictions are weak, i.e. the firm can change prices fairly easily to adjust to the exchange rate movement. Naturally, as prices become more rigid, the presence of deep habits further diminishes the pass-through of exchange rate fluctuations to international prices.

Deep habits, originally modelled in Ravn, Schmitt-Grohé, and Uribe (2006), considers the possibility that consumers form habits separately over more narrowly defined categories of goods and not at the level of final consumption expenditures. A consequence of this type of habit persistence is that the demand for the individual good is influenced by a predetermined component so that the firm's profit-maximizaton program becomes intertemporal, irrespective of the presence of price rigidities. In an economy with deep habits, a unit sale generates profits not merely in the current period but also into the future due to the strength of habit persistence. The firm takes into account future demand in its profit maximization problem. Importantly, in this environment, a change in price has strong effects on the entire trajectory of future demand. In the context of the open economy, the importer realizes that passing through a depreciation of the exchange rate to the consumer by strongly raising prices, may result in a loss of demand stretching far into the future. For this

\footnotetext{
${ }^{1}$ See Burstein and Gopinath (2014) for a comprehensive review of the literature.
} 
reason, the importing firm has an incentive to partially absorb the exchange rate movement into its price markup. In sum, in our model, sticky demand - as opposed to sticky prices - can generate markup adjustments and deliver inertial pass-through of nominal exchange rate fluctuations into import prices.

We demonstrate that low pass-through can be obtained both by strengthening deep habits at low degrees of price stickiness modelled using standard convex adjustment costs à la Rotemberg (1982), and - as in the conventional case - by abstracting from habits and merely increasing price adjustment costs. Used in conjunction, deep habits and sticky prices dampen import price movements easily, since both frictions enhance the absorption of the exchange rate fluctuation into the import price markup. We then empirically validate the deep habits model by matching the dynamics of the model triggered by an exchange rate shock to those induced by an identified shock to the US nominal effective exchange rate in a vector autoregression (VAR). Again, we find that deep habits and sticky prices complement each other in helping the model generate the dynamics observed in the VAR. In contrast, when we deactivate the deep habits channel, the model requires implausibly high values for the price adjustment cost parameter, to replicate the VAR evidence.

We build on the work of Ravn, Schmitt-Grohé, and Uribe (2012, 2007) who demonstrate how the presence of deep habits can influence firms to price-to-market. In the deep habits economy, firms face more elastic demand functions in markets where current demand is high relative to habitual demand, creating an incentive to price discriminate across markets. In contrast to Ravn, SchmittGrohé, and Uribe $(2012,2007)$, we delve deeper into incomplete exchange rate pass-through which is a consequence of pricing-to-market and markup adjustment by firms. While the economy we consider preserves the price elasticity effect of deep habits detailed by Ravn, Schmitt-Grohé, and Uribe $(2012,2007)$, we additionally emphasize the intertemporal sales smoothing incentive of firms facing dynamic demand functions.

Departing from the flexible price framework of Ravn, Schmitt-Grohé, and Uribe (2012, 2007), we adopt the New Keynesian environment. The introduction of nominal rigidities enables us to explicitly study the link between nominal exchange rate fluctuations and nominal prices as in the microeconometric literature (see Burstein and Gopinath, 2014). From a modelling standpoint, nominal rigidities fundamentally alter the deep habits environment and its influence on exchange rate pass-through, since monetary policy and nominal exchange rate fluctuations influence the effective discount rate used by firms to evaluate expected profits from international sales. When 
nominal interest rates or exchange rates adjust to structural shocks, they lower the discount rate used to evaluate profits from export sales. This in turn implies that the present value of future export sales is raised. Consequently, the firm will resist transmitting the exchange rate fluctuation to the sales price, and instead partially absorb the currency fluctuation into the price markup. We study the correlation between import price inflation and exchange rate depreciation conditional on two structural shocks found to be important drivers of the exchange rate in estimated DSGE models: shocks to strict uncovered interest parity (UIP) and monetary policy. ${ }^{2}$

The literature has seen diverse theoretical models of real rigidities that deliver deviations in the law of one price in flexible price environments similar to that of Ravn, Schmitt-Grohé, and Uribe (2012, 2007). In this set of papers, international price markups have variously been influenced by local distribution costs (Corsetti and Dedola, 2005), market shares (Atkeson and Burstein, 2008), consumer search costs (Alessandria, 2009), inventory considerations (Alessandria, Kaboski, and Midrigan, 2010) or prices relative to that of the competitors (Gust, Leduc, and Vigfusson, 2010). The deep habits model is in spirit akin to the 'customers as capital' framework of Drozd and Nosal (2012b), in which firms need to build market shares by matching with their customers, and market segmentation yields markup adjustment and departures from the law of one price. The dynamic acquisition of customers is latent in the formulation of deep habits.

The unified treatment of the potential interaction between frictions on the real and nominal sides in determining the degree of exchange rate pass-through aligns our analysis with that of Corsetti, Dedola, and Leduc (2008a). They study the interaction of distribution costs à la Corsetti and Dedola (2005) and local currency import price stickiness in a New Keynesian two-country model similar to ours. The important distinction, apart from the emphasis on a different real rigidity, is that we take our model to the data. Our empirical strategy is adapted from Choudhri, Faruqee, and Hakura (2005) and Smets and Wouters (2002) who match the dynamics of the model triggered by a random deviation from uncovered interest parity, to those observed conditional on an identified exchange rate shock in a VAR. The estimation of the deep habits model also relates our paper to that of Ravn, Schmitt-Grohé, and Uribe (2012) and Ravn, Schmitt-Grohé, Uribe, and Uusküla (2010b) who match the dynamics of deep habits models to VAR-based impulse responses conditional on shocks to government spending and monetary policy respectively. ${ }^{3}$

\footnotetext{
${ }^{2}$ See e.g. Rabanal and Tuesta (2010) and Bergin (2006).

${ }^{3}$ In a different context, Lubik and Teo (2014) find empirical support in favor of the influence of deep habits in reducing the degree of intrinsic inflation persistence in a single equation estimation of the closed-economy New Keynesian Phillips Curve.
} 
Finally, Ravn, Schmitt-Grohé, and Uribe (2010a) demonstrate the ability of deep habits to generate incomplete pass-through of idiosyncratic cost shocks to the firm's price level. Since a movement in the exchange rate alters the cost structure of the firm that produces internationally traded goods, at its heart, the general equilibrium treatment of exchange rate pass-through presented in this paper, is a generalization of the partial-equilibrium, closed-economy analysis of Ravn, Schmitt-Grohé, and Uribe (2010a).

The remainder of this paper is set out as follows. In the next section, we introduce deep habits into an otherwise standard two-country New Keynesian model environment and describe the primitive optimality conditions. Section 3 focuses on the log-linearized version of the model to understand how deep habits and sticky prices influence the firm's markup adjustment and the related implications for the pass-through of exchange rate fluctuations to international prices. In Section 4, we compare the empirical performance of the New Keynesian model with deep habits to that of a restricted version that abstracts from deep habits. Section 5 draws the main conclusions.

\section{A Two-Country Model with Deep Habits}

\subsection{Preliminaries}

The model involves two symmetric countries populated by representative households and firms. Each country specializes in the production of a set of differentiated goods. We denote by $a(b)$ the set of goods produced by the home (foreign) country. Also, the model abstracts from capital accumulation, government spending, and non-traded goods. Only the home country's problem is described here. The exposition of the model is based on Ravn, Schmitt-Grohé, and Uribe (2012, 2007). Typically, a variable $z$ in the non-stochastic steady-state is presented as $\bar{z}$. A logarithmic deviation of the variable relative to its steady-state in period $t$ is represented as $\hat{z}_{t} \equiv \frac{\partial z_{t}}{\bar{z}}=\log \frac{z_{t}}{\bar{z}}$. $\mathbb{E}$ represents the conditional expectations operator while $\Delta$ indicates the temporal difference operator. In the interests of notational brevity, we avoid using the period $t$ subscript when we describe variables and functional forms in the main text, unless we refer to a dynamic relationship. We also suppress the indexation of the variable to the state of nature. The comprehensive derivation of the model is available on request. 


\subsection{Households}

The domestic economy is populated by a large number of identical households indexed by $j$, with preferences described by the utility function:

$$
\mathbb{E}_{0} \sum_{t=0}^{\infty} \beta^{t} \mathbb{U}\left(\chi_{t}^{j}, n_{t}^{j}\right)
$$

where

$$
\chi_{t}=\left(\omega^{\frac{1}{\xi}} x_{a, t}^{\frac{\xi-1}{\xi}}+(1-\omega)^{\frac{1}{\xi}} x_{b, t}^{\frac{\xi-1}{\xi}}\right)^{\frac{\xi}{\xi-1}}
$$

and

$$
\mathbb{U}\left(\chi_{t}, n_{t}\right)=\frac{\left(\chi_{t}^{\phi}\left(1-n_{t}\right)^{(1-\phi)}\right)^{1-\sigma_{c}}-1}{\left(1-\sigma_{c}\right)}
$$

such that $\beta \in(0,1), \omega, \phi \in[0,1], \xi, \sigma_{c}>0$.

The variable $\chi$ is a consumption aggregate that is formed by combining a home goods aggregate $x_{a}$ and an imported aggregate $x_{b}$ from the foreign country in Equation (2). The preferences defined over the consumption aggregate and hours worked $n$ are given a standard CES form in Equation $(3)$.

\subsubsection{Deep Habits}

As in Ravn, Schmitt-Grohé, and Uribe (2006), the household forms habits at the level of the individual goods variety produced by the monopolistic firm, as opposed to the aggregated final good. This type of habit-formation is referred to as 'deep' or good-specific habits as it differs from the 'superficial' habits formed at the level of the aggregate good as in standard models (see e.g. Jacob and Peersman, 2013 and Adolfson et al., 2007). Furthermore, habits are assumed to be external to the individual household, so that the level of average consumption in previous periods is the reference point for the household in their consumption decision. More formally, we can represent habit-adjusted consumption by: ${ }^{4}$

$$
x_{a, t}=\left[\int_{0}^{1}\left(c_{i, a, t}-h_{a} s_{i, a, t-1}\right)^{1-1 / \eta_{c}} d i\right]^{\frac{1}{1-1 / \eta_{c}}}, h_{a} \in[0,1), \eta_{c}>1 .
$$

\footnotetext{
${ }^{4}$ For expositional reasons, we will ignore the superscript $j$ for each household in the remainder of section 2.2.1.
} 
The variable $c_{i, a}$ denotes the consumption of variety $i$ of goods belonging to the set $a$. The parameter $h_{a}$ governs the degree of habit persistence and in the absence of habit-formation, i.e. $h_{a}=0$, the parameter $\eta_{c}$ denotes the elasticity of substitution between goods varieties. For $h_{a}>0, \eta_{c}$ represents the long-run price elasticity of habit-adjusted demand for the goods variety. The variable $s_{i, a}$ denotes the external habit stock of variety $i$ of good $a$ and evolves according to the law of motion:

$$
s_{i, a, t}=\rho_{a} s_{i, a, t-1}+\left(1-\rho_{a}\right) \tilde{c}_{i, a, t}, \rho_{a} \in[0,1) .
$$

The variable $\tilde{c}_{i, a}$ is the per capita consumption of good $i$ of good $a$ in the home country. The parameter $\rho_{a}$ denotes the persistence of the habit stock so that $\left(1-\rho_{a}\right)$ indicates the rate at which the habit stock decays over time.

The household distributes its expenditures over all the goods varieties and the demand for the individual variety is determined by the cost-minimization program $\min _{c_{i, a, t}} \int_{0}^{1} P_{i, a, t} c_{i, a, t}$ subject to Equation (4). The demand for good $i$ of type $a$ is given by:

$$
c_{i, a, t}=\left(\frac{P_{i, a, t}}{P_{a, t}}\right)^{-\eta_{c}} x_{a, t}+h_{a} s_{i, a, t-1}
$$

where $P_{a}=\left(\int_{0}^{1} P_{i, a}^{1-\eta_{c}} d i\right)^{\frac{1}{1-\eta_{c}}}$ indicates a price level for habit-adjusted demand for goods of type $a$. The demand for each variety is decreasing in its relative price $P_{i, a} / P_{a}$ and increasing in $x_{a}$ the level of habit-adjusted consumption of the composite good of type $a$ as well as the habit stock $s_{i, a}$. Total expenditure on goods of type $a$ in period $t$ can be expressed as $\int_{0}^{1} P_{i, a} c_{i, a} d i=P_{a} x_{a}+\omega_{a}$ such that $\omega_{a, t}=h_{a} \int_{0}^{1} P_{i, a, t} s_{i, a, t-1} d i$.

Imports of good $b$ from the foreign country is similarly influenced by habit persistence and the demand for the individual imported variety mirrors that for the home variety:

$$
c_{i, b, t}=\left(\frac{P_{i, b, t}}{P_{b, t}}\right)^{-\eta_{c}} x_{b, t}+h_{b} s_{i, b, t-1}
$$

Ravn, Schmitt-Grohé, and Uribe (2006) demonstrate that the lag structure of the demand functions for the individual varieties alters the firms' price-setting behavior and induces price markup adjustment in response to structural shocks. In Section 3.1, we highlight the role of the predetermined component of import demand in Equation (7) in determining import price markup adjustment and 
the degree of exchange rate pass-through.

\subsubsection{Budget Constraint and Optimality Conditions}

In each period, each household $j$ have access to complete contingent claims markets. The variable $d$ represents the state-contingent asset and let $r_{t, t+k}$ denote the nominal stochastic discount factor such that $\mathbb{E}_{t} r_{t, t+k} d_{t+k}$ is the period- $t$ price of a random payment of the numeraire good in period $t+k$. In addition, households are assumed to be entitled to the receipts of profits $\Pi$ from the ownership of firms. As in Erceg, Henderson, and Levin (2000), each household is a monopolistic supplier of specialised labor $n^{j}$. A large number of perfectly competitive 'employment agencies' aggregates the specialised labor-varieties from the households into a homogenous labor input $n$ using a CES technology and sells it to the representative firm. The employment agency returns to the household a labor-type specific nominal wage $W^{j}$. The demand function for the labor-type from the firm is given as $n^{j}=\left(W^{j} / W\right)^{-\eta_{n}} n$ with $\eta_{n}>1$ representing the relative wage elasticity. We also introduce nominal wage rigidities by stipulating that it is costly à la Rotemberg (1982), to change wages. The parameter $\psi_{w} \geqslant 0$ governs the strength of the wage adjustment cost.

The domestic representative household's period-by-period budget constraint is given by:

$$
P_{a, t} x_{a, t}^{j}+\omega_{a, t}^{j}+P_{b, t} x_{b, t}^{j}+\omega_{b, t}^{j}+\mathbb{E}_{t} r_{t, t+1} d_{t+1}^{j}+\frac{\psi_{w}}{2} W_{t} n_{t}\left(\frac{W_{t}^{j}}{\bar{\pi}^{n w} W_{t-1}^{j}}-1\right)^{2}=d_{t}^{j}+W_{t}^{j} n_{t}^{j}+\Pi_{t}^{j} .
$$

In addition, households are assumed to be subject to a borrowing constraint of the form $\lim _{t \rightarrow \infty} \mathbb{E}_{t} r_{t, t+z} d_{t+z} \geqslant 0$ which prevents them from engaging in Ponzi Games. The household's optimization problem consists in choosing processes $x_{a, t}^{j}, x_{b, t}^{j}, W_{t}^{j}$, and $d_{t+1}^{j}$ to maximize the lifetime utility function (1) subject to Equations (2) and (8), labor demand, and the No-ponzi-game constraints, taking as given the processes for $\omega_{a, t}, \omega_{b, t}$, firm profits $\Pi_{t}$, and the initial asset holding $d_{0}$. We describe the optimality conditions in a symmetric equilibrium. The marginal rate of substitution between home and foreign good aggregates equals the ratio of their respective prices:

$$
\frac{\chi_{x_{a, t}}}{\chi_{x_{b, t}}}=\frac{P_{a, t}}{P_{b, t}}
$$

The standard asset pricing relation equates the price of contingent claims to the intertemporal 
marginal rate of substitution:

$$
\mathbb{U}_{\chi, t} \chi_{x_{a, t}} r_{t, t+1}=\beta \mathbb{E}_{t} \frac{\mathbb{U}_{\chi, t+1} \chi_{x_{a, t+1}}}{\pi_{a, t+1}},
$$

where gross inflation $\pi_{a, t+1}=P_{a, t+1} / P_{a, t}$. Finally, optimal wage-setting implies that wage adjustment costs drives a wedge between the marginal rate of substitution between consumption and labor, and the domestic composite good-based real wage $\left(w_{a}=W / P_{a}\right)$ :

$$
\begin{aligned}
& \mathbb{E}_{t} \beta \frac{\mathbb{U}_{\chi, t+1}}{\mathbb{U}_{\chi, t}} \frac{\chi_{x_{a, t+1}}}{\chi_{x_{a, t}}} \frac{n_{t+1}}{n_{t}} \frac{\left(\pi_{t+1}^{n w}\right)^{2}}{\pi_{a, t+1} \bar{\pi}^{n w}} \psi_{w}\left(\frac{\pi_{t+1}^{n w}}{\bar{\pi}^{n w}}-1\right) \\
= & \frac{\pi_{t}^{n w}}{\bar{\pi}^{n w}} \psi_{w}\left(\frac{\pi_{t}^{n w}}{\bar{\pi}^{n w}}-1\right)+\eta_{n}\left[1-\frac{\psi_{w}}{2}\left(\frac{\pi_{t}^{n w}}{\bar{\pi}^{n w}}-1\right)^{2}-\frac{\mathbb{U}_{n, t}}{\mathbb{U}_{\chi, t} \chi_{x_{a, t}} w_{a, t}}\right]-1,
\end{aligned}
$$

where $\pi^{n w}$ indicates the gross rate of nominal wage inflation. International financial markets are assumed to be complete and, consequently, the home and foreign households have access to the same state-contingent assets. If we additionally assume that the two countries are equally wealthy, we obtain the international risk-sharing condition, where the good $a$-based real exchange rate $\left(r e r_{a}=n e r P_{a}^{*} / P_{a}\right)$ is tied down by the ratio of the marginal utilities of the two countries:

$$
\frac{\mathbb{U}_{\chi, t}^{*} \chi_{x_{a, t}^{*}}^{*}}{\mathbb{U}_{\chi, t} \chi_{x_{a, t}}}=r e r_{a, t} .
$$

We generate business cycle fluctuations by using two distinct stochastic processes. The first cyclical disturbance $z^{\text {uip }}$ perturbs the UIP condition in Equation (13) which pins down the expected depreciation of the domestic currency to the differential in nominal home and foreign country interest rates, $R$ and $R^{*}:^{5}$

$$
\begin{gathered}
\frac{\mathbb{E}_{t} n e r_{t+1}}{n e r_{t}}=\frac{R_{t}}{R_{t}^{*} z_{t}^{u i p}} \\
\text { where } \log z_{t}^{u i p}=\left(1-\rho_{\text {uip }}\right) \log \bar{z}^{u i p}+\rho_{\text {uip }} \log z_{t-1}^{\text {uip }}+\vartheta_{t}^{u i p}, \vartheta_{t}^{u i p} \sim \mathbb{N}\left(0, \sigma_{\text {uip }}\right) .
\end{gathered}
$$

Devereux and Engel (2002) attribute the random deviation from strict interest parity to misaligned expectations from foreign currency traders on the evolution of the currency's value. Alternatively, in McCallum and Nelson (1999), this shock is interpreted as a time-varying risk premium which

\footnotetext{
${ }^{5}$ The UIP condition is obtained by equating the nominal stochastic discount factors (expressed in the same currency) across the two countries. In equilibrium, the interest rate $R$ is the reciprocal of the expected value of the contingent-claim prices $r_{t, t+1}$.
} 
is omitted by linearization. The UIP shock is frequently used in the set of cyclical disturbances employed in the estimation of open-economy DSGE models (e.g. Jacob and Peersman, 2013, Adolfson et al., 2007, and Bergin, 2006) and typically explains much of the forecast variance of the exchange rate.

The second business cycle shock $z^{\text {mon }}$ stimulates the Taylor-type rule that is used by the monetary authority to set the nominal interest rate:

$$
\begin{aligned}
\frac{R_{t}}{\bar{R}} & =\left(\frac{R_{t-1}}{\bar{R}}\right)^{r_{R}}+\left(\frac{\pi_{a, t}}{\bar{\pi}_{a}}\right)^{\left(1-r_{R}\right) r_{\pi}}\left(\frac{y_{t}}{\bar{y}}\right)^{\left(1-r_{R}\right) r_{y}} z_{t}^{\text {mon }}, \\
\text { where } \log z_{t}^{\text {mon }} & =\left(1-\rho_{\text {mon }}\right) \log \bar{z}^{\text {mon }}+\rho_{\text {mon }} \log z_{t-1}^{\text {mon }}+\vartheta_{t}^{\text {mon }}, \vartheta_{t}^{\text {mon }} \sim \mathbb{N}\left(0, \sigma_{\text {mon }}\right) .
\end{aligned}
$$

\section{$2.3 \quad$ Firms}

Each individual variety of good $a$ is assumed to be produced by a monopolist. The variety indexed by $i \in[0,1]$ is manufactured using labor as the sole input in a linear production function:

$$
y_{i, a, t}=n_{i, a, t}
$$

$y_{i, a}$ is the production of variety $i$ and $n_{i, a}$ is the labor required to produce it. The producer of variety $i$ faces demands from the private sector at home and abroad respectively:

$$
\begin{aligned}
& c_{i, a, t}=\left(\frac{P_{i, a, t}}{P_{a, t}}\right)^{-\eta_{c}} x_{a, t}+h_{a} s_{i, a, t-1} . \\
& c_{i, a, t}^{*}=\left(\frac{P_{i, a, t}^{*}}{P_{a, t}^{*}}\right)^{-\eta_{c}} x_{a, t}^{*}+h_{a}^{*} s_{i, a, t-1}^{*} .
\end{aligned}
$$

The consumer's optimal choices in Equations (9), (10), and (11) in the deep habits economy are indistinguishable from those that would prevail in an economy of habit persistence at the level of the aggregated good. However, from the perspective of the firm, deep habits alters profitmaximization in fundamental ways. Observe that the first component of each demand function, $\left(P_{i} / P\right)^{-\eta_{c}} x$, is price-elastic while the second component $h s_{i, t-1}$ is purely predetermined. The habit term makes the firm's program comparable to a situation where procurement relationships are formed between buyers and sellers, where the buyer favors the seller that supplied the good in the past. Consequently, predetermined sales quantities affect pricing behavior. 
The price elasticity of demand $-\left(\partial c_{i, t} / \partial p_{i, t}\right)\left(p_{i, t} / c_{i, t}\right)$ is now time-varying and in a symmetric equilibrium can be expressed as $\epsilon_{t}=\eta_{c}\left(1-h s_{t-1} / c_{t}\right)$. In its log-linear form, the price elasticity is a function of the degree of habit persistence as well as growth in aggregate demand, i.e. $\hat{\epsilon}_{t}=$ $\frac{h}{1-h}\left(\hat{c}_{t}-\hat{s}_{t-1}\right)$. If demand conditions differ across regions in the two-country environment, the country-specific short-run price elasticities vary and hence the firm can use different price markups between home and foreign markets. This leads to endogenous deviations from the law of one price.

Price-Setting Problem The firm $i$ chooses labor input $\left\{n_{i, a, t}\right\}_{t=0}^{\infty}$, prices $\left\{P_{i, a, t}, P_{i, a, t}^{*}\right\}_{t=0}^{\infty}$, and quantities $\left\{c_{i, a, t}, s_{i, a, t}, c_{i, a, t}^{*}, s_{i, a, t}^{*}\right\}_{t=0}^{\infty}$ to maximize the discounted expected value from profits, taking as given $r_{0, t}, W_{t}, P_{a, t}, P_{a, t}^{*}, x_{a, t}, x_{a, t}^{*}$, and the initial conditions. The constraints that it faces are the goods market clearing condition, the demand functions at home and abroad, and the flow of habit stocks. The firm incurs Rotemberg-type quadratic costs $\Psi_{a, t}()$ and $\Psi_{a, t}^{*}()$ in adjusting nominal prices for domestic and export sales respectively. ${ }^{6}$ The firm sets the export price $P_{i, a}^{*}$ in foreign currency, a model feature known in the literature as local currency pricing (see Burstein and Gopinath, 2014). ${ }^{7}$

Revenue from export sales is evaluated in terms of home currency by using the nominal exchange rate ner, a rise in which indicates a depreciation of the home currency. The optimization program that the firm faces is formally given as:

$$
\max _{\substack{n_{i, t}, P_{i, a, t} P_{i, a, t}^{*} \\ c_{i, a, t}, s_{i, a, t}, c_{i, a, t}^{*} s_{i, a, t}^{*}}} \mathbb{E}_{0} \sum_{t=0}^{\infty} r_{0, t}\left(P_{i, a, t} c_{i, a, t}+n e r_{t} P_{i, a, t}^{*} c_{i, a, t}^{*}-W_{t} n_{i, t}-\Psi_{a, t}-n e r_{t} \Psi_{a, t}^{*}\right),
$$

subject to

$$
\begin{gathered}
y_{i, t}=c_{i, a, t}+c_{i, a, t}^{*} \text { where } y_{i, t}=n_{i, t}, \\
c_{i, a, t}=\left(\frac{P_{i, a, t}}{P_{a, t}}\right)^{-\eta_{c}} x_{a, t}+h_{a} s_{i, a, t-1}, \\
c_{i, a, t}^{*}=\left(\frac{P_{i, a, t}^{*}}{P_{a, t}^{*}}\right)^{-\eta_{c}} x_{a, t}^{*}+h_{a}^{*} s_{i, a, t-1}^{*},
\end{gathered}
$$

\footnotetext{
${ }^{6}$ The presence of deep habits makes the pricing problem dynamic even in the absence of nominal rigidities. Since accounting for additional dynamics due to Calvo (1983)-style pricing makes aggregation non-trivial, models with deep habits typically use Rotemberg pricing. Up to a first-order approximation, the two pricing frictions yield observationally equivalent dynamics.

${ }^{7}$ Alternatively, if export sales were priced in home currency ('producer currency pricing'), the price at which the foreign country procures the exports of the home country, would simply be the foreign-currency equivalent of the price that the home country firm sets for domestic sales. Hence, the pass-through of exchange rate fluctuations would be high, irrespective of the presence of deep habits.
} 


$$
\begin{gathered}
s_{i, a, t}=\rho_{a} s_{i, a, t-1}+\left(1-\rho_{a}\right) c_{i, a, t}, \\
s_{i, a, t}^{*}=\rho_{a}^{*} s_{i, a, t-1}^{*}+\left(1-\rho_{a}^{*}\right) c_{i, a, t}^{*}, \\
\Psi_{a, t}=c_{a, t} P_{a, t} \frac{\psi_{a}}{2}\left(\frac{P_{i, a, t}}{\bar{\pi}_{a} P_{i, a, t-1}}-1\right)^{2}, \psi_{a} \geq 0, \\
\Psi_{a, t}^{*}=c_{a, t}^{*} P_{a, t}^{*} \frac{\psi_{a}^{*}}{2}\left(\frac{P_{i, a, t}^{*}}{\bar{\pi}_{a}^{*} P_{i, a, t-1}^{*}}-1\right)^{2}, \psi_{a}^{*} \geq 0,
\end{gathered}
$$

with the nominal Lagrange multipliers $n m c, V_{i, a} \equiv P_{a} \nu_{i, a}, \Lambda_{i, a} \equiv P_{a} \lambda_{i, a}, V_{i, a}^{*} \equiv \operatorname{ner} P_{a}^{*} \nu_{i, a}^{*}$ and $\Lambda_{i, a}^{*} \equiv n e r P_{a}^{*} \lambda_{i, a}^{*}$ attached to the constraints in Equations (20), (21), (22), (23), and (24) respectively. The multiplier $n m c$ associated with the goods market clearing condition is the nominal marginal cost. The multipliers $\nu_{i, a}$ and $\nu_{i, a}^{*}$ attached to the demand function constraints indicate the incremental profit (in real terms) that the firm gains when it sells a unit of the goods variety at home and abroad respectively. Similarly, the multipliers $\lambda_{i, a}$ and $\lambda_{i, a}^{*}$ attached to the laws of the motion of the habit stocks, measure the real marginal profits gained from changes in the habit stocks. We will consider the optimality conditions in a symmetric equilibrium. The first order condition for labor equates the nominal marginal cost to the nominal wage, i.e. $n m c_{t}=W_{t}$. The optimal choice of domestic sales $c_{a}$ provides a law of motion for the real marginal profit $\nu_{a}$ of selling a unit of the good:

$$
\nu_{a, t}=1+\lambda_{a, t}\left(1-\rho_{a}\right)-\frac{n m c_{t}}{P_{a, t}} .
$$

The real marginal profit equals the difference between the real marginal cost $n m c / P_{a}$ and the real marginal revenue which in turn, has two components. The first component is the unit real revenue 1 in the current period. In addition, due to habit persistence, selling a unit of the good in the current period also generates a stream of sales in the future and $\lambda_{a}$ represents the present value of the future marginal profits generated. The present value $\lambda_{a}$ is in turn determined by the optimal choice of the habit stock $s_{a}$ :

$$
\lambda_{a, t}=\mathbb{E}_{t} r_{t, t+1} \pi_{a, t+1}\left(h_{a} \nu_{a, t+1}+\rho_{a} \lambda_{a, t+1}\right)
$$

An increment in the habit stock in the current period generates sales of $h_{a}$ units in the ensuing period and expected marginal profits $\mathbb{E}_{t} \nu_{a, t+1}$ associated with that sale. The persistence of the habit stock $\rho_{a}$ determines the degree to which the present value of marginal profits is affected by the next period's expectation of marginal profits from future sales. 
The first order conditions for export sales $c_{a}^{*}$ and export habit stock $s_{a}^{*}$ are almost isomorphic to those for domestic sales:

$$
\begin{gathered}
\nu_{a, t}^{*}=1+\lambda_{a, t}^{*}\left(1-\rho_{a}^{*}\right)-\frac{n m c_{t}}{n e r_{t} P_{a, t}^{*}} \\
\lambda_{a, t}^{*}=\mathbb{E}_{t} r_{t, t+1} \pi_{t+1}^{n e r} \pi_{a, t+1}^{*}\left(h_{a}^{*} \nu_{a, t+1}^{*}+\rho_{a}^{*} \lambda_{a, t+1}^{*}\right) .
\end{gathered}
$$

Since the firm prices the exports $P_{a}^{*}$ in the foreign currency, the nominal exchange rate enters these equilibrium conditions through its influence on the markup and profits. The real marginal cost of the exporter is given by $n m c /\left(n e r P_{a}^{*}\right)$ and the relevant price markup is simply its reciprocal: $\mu_{a}^{*}=n e r P_{a}^{*} / n m c$. The effective discount factor used by the firm to evaluate marginal profits from future foreign sales is distinct from the analog for domestic sales. In particular, the expected depreciation of the home currency, indicated by $\pi_{t+1}^{n e r}=n e r_{t+1} / n e r_{t}$ affects the discount rate. This is because the marginal profits $\nu_{a}^{*}$ and $\lambda_{a}^{*}$ are by definition, 'real' in terms of the home currency equivalent of the export price which is set in foreign currency. In the absence of deep habits, the present value of future profits $\lambda_{a}^{*}$ as well as the effective discount rate are auxilliary variables, and do not play significant roles in the firm's decision problem. This implies that the real marginal profit can be obtained by a simple rescaling of the price markup: $\nu_{a}^{*}=\left(\mu_{a}^{*}-1\right) / \mu_{a}^{*}$.

Optimality implies the following paths for inflation in home and foreign sales price:

$$
\mathbb{E}_{t} r_{t, t+1} \frac{c_{a, t+1}}{c_{a, t}} \frac{\pi_{a, t+1}^{2}}{\bar{\pi}_{a}} \psi_{a}\left(\frac{\pi_{a, t+1}}{\bar{\pi}_{a}}-1\right)=\frac{\pi_{a, t}}{\bar{\pi}_{a}} \psi_{a}\left(\frac{\pi_{a, t}}{\bar{\pi}_{a}}-1\right)+\eta_{c} \frac{x_{a, t} \nu_{a, t}}{c_{a, t}}-1,
$$

and

$$
\mathbb{E}_{t} r_{t, t+1} \frac{c_{a, t+1}^{*}}{c_{a, t}^{*}} \frac{\pi_{t+1}^{n e r}\left(\pi_{a, t+1}^{*}\right)^{2}}{\bar{\pi}_{a}^{*}} \psi_{a}^{*}\left(\frac{\pi_{a, t+1}^{*}}{\bar{\pi}_{a}^{*}}-1\right)=\frac{\pi_{a, t}^{*}}{\bar{\pi}_{a}^{*}} \psi_{a}^{*}\left(\frac{\pi_{a, t}^{*}}{\bar{\pi}_{a}^{*}}-1\right)+\eta_{c} \frac{x_{a, t}^{*} \nu_{a, t}^{*}}{c_{a, t}^{*}}-1 .
$$

As in traditional sticky price models, these optimal pricing conditions pin down the expected evolution of inflation to the real marginal cost or, equivalently, the price markup. However in the presence of deep habits, the relation of inflation to the real marginal cost is indirect, through the marginal profits $\nu_{a}^{*}$ and $\nu_{a}^{*}$ presented in Equations (27) and (29). We defer the discussion on pricing behavior under deep habits to Section 3.1 when we examine the extent of exchange rate pass-through in the first-order approximation of the model. We will now focus on equilibrium conditions that have been log-linearized around a non-stochastic steady-state that abstracts from growth in all variables. 


\section{Price Markups and Exchange Rate Fluctuations}

Here we examine the transmission of exchange rate fluctuations into the foreign economy's export prices. In the empirics that will follow in Section 4, the US will be positioned as the home country in the model while the foreign economy is the rest of the world (RoW). The discussion in the empirical analysis, centres on the dynamics of the US import price. In the context of the model developed here, the US import price is simply the export price of the foreign economy. We begin by analyzing the composition on the foreign exporter's Phillips curve and how the exchange rate affects the price markup in Section 3.1. In Section 3.2, we simulate the log-linearized model to illustrate how deep habits and price stickiness interact each other to diminish exchange rate pass-through, conditional on UIP and home monetary policy shocks.

\subsection{The Foreign Exporter's Phillips Curve}

We now present the log-linearized analogs of Equations (29), (30), and (32), the optimal choices of sales quantity, habit stock and price for the foreign exporter. The foreign exporter's optimal choice of export sales $c_{b}$ implies that the real marginal profit $\nu_{b}$ covaries positively with the export price markup $\mu_{b}$ and $\lambda_{b}$, the present value of marginal profits from future sales. If the foreign exporter's price markup is defined as the ratio of $P_{b}$ the export sales price to the foreign nominal marginal cost $n m c^{*}$ expressed in the same currency, i.e. $\mu_{b}=\left(P_{b} / n e r\right) / n m c^{*}$, the real marginal profit flows as:

$$
\hat{\nu}_{b, t}=\frac{1}{\bar{\nu}_{b} \bar{\mu}_{b}} \hat{\mu}_{b, t}+\left(1-\rho_{b}\right) \frac{\beta h_{b}}{1-\beta \rho_{b}} \hat{\lambda}_{b, t}
$$

The present value of future marginal profits from the optimal choice of habit stock $s_{b}$ evolves as:

$$
\hat{\lambda}_{b, t}=\left(1-\beta \rho_{b}\right) \mathbb{E}_{t} \hat{\nu}_{b, t+1}+\beta \rho_{b} \mathbb{E}_{t} \hat{\lambda}_{b, t+1}-\left[\hat{R}_{t}^{*}-\mathbb{E}_{t}\left(\hat{\pi}_{b, t+1}-\hat{\pi}_{t+1}^{n e r}\right)\right]
$$

Observe the effect of the expected changes in the exchange rate, on the effective discount rate used by the foreign exporter to evaluate future profits. A change in the value of the currency alters the present value of future profits. For instance, if the home currency is expected to depreciate, i.e. $\mathbb{E}_{t} \hat{\pi}_{t+1}^{n e r}>0$, the effective real discount rate increases which depresses the present value of profits. Finally, changes in the foreign exporter's optimal price are determined by:

$$
\hat{\pi}_{b, t}=\beta \mathbb{E}_{t} \hat{\pi}_{b, t+1}-\frac{1}{\psi_{b}}\left(\hat{\nu}_{b, t}+\hat{x}_{b, t}-\hat{c}_{b, t}\right) .
$$


We will now establish the direct link between foreign export price inflation and the foreign export price markup which subsumes the nominal exchange rate. To distill the intuition, it is useful to abstract from persistence in the habit stock, i.e. set $\rho_{b}=0$. This adjustment implies that the present value of expected future profits reduces to:

$$
\hat{\lambda}_{b, t}^{\prime}=\mathbb{E}_{t} \hat{\nu}_{b, t+1}-\left[\hat{R}_{t}^{*}-\mathbb{E}_{t}\left(\hat{\pi}_{b, t+1}-\hat{\pi}_{t+1}^{n e r}\right)\right]
$$

The adjusted steady-state export markup can be simplified as:

$$
\bar{\mu}_{b}^{\prime}=\frac{\eta_{c}\left(1-h_{b}\right)}{\eta_{c}\left(1-h_{b}\right)-\left(1-\beta h_{b}\right)} .
$$

Substitute the following into Equation (35): the steady-state real marginal profit $1 / \bar{\nu}_{b}=\eta_{c}\left(1-h_{b}\right)$, the dynamics of the real marginal profit in Equation (33), the steady-state markup in Equation (37), and the definition of aggregate habit-adjusted demand, $\hat{x}_{b, t}=\frac{\hat{c}_{b, t}-h_{b} \hat{c}_{b, t-1}}{1-h_{b}} .8$ The dynamics of the export markup, i.e. the wedge between the foreign export price and the foreign marginal cost expressed in the same currency, is given by:

$$
\underbrace{\left(\hat{p}_{b, t}-\widehat{n m}_{t}^{*}-\widehat{n e r}_{t}\right)}_{\hat{\mu}_{b, t}}=\frac{\beta \psi_{b} \mathbb{E}_{t} \hat{\pi}_{b, t+1}-\psi_{b} \hat{\pi}_{b, t}-\left(\beta h_{b} \hat{\lambda}_{b, t}^{\prime}+\hat{\varepsilon}_{b, t}\right)}{\eta_{c}\left(1-h_{b}\right)-\left(1-\beta h_{b}\right)} .
$$

where $\hat{\varepsilon}_{b, t}=\frac{h_{b}}{1-h_{b}} \Delta \hat{c}_{b, t}$ is the relevant short-run price elasticity of demand. Other things constant, consider an exogenous depreciation of the home currency, i.e. a rise in the exchange rate so that $\widehat{n e r}_{t}>0$. This affects the exporter's price markup in distinct ways. Firstly, the fall in the value of the currency in which the export is priced, depresses the exporter's price markup. This effect is due to the definition of the foreign export price markup, and is relevant even in the absence of deep habits. However, the present of the habit component implies that the reduction in the current markup (or prices) while positively stimulating current export demand, also generates profits into the future. When the home currency depreciates, the economy expects it to appreciate in the future so that it returns to the long run level i.e. $\mathbb{E}_{t} \hat{\pi}_{t+1}^{n e r}<0$. The expected appreciation raises the present value of future profits $\hat{\lambda}_{b, t}^{\prime}$ which gives the foreign exporter an incentive to keep the current markup low, and prices stable (see Equation 34). Finally, the reduction of the markup can be reinforced by a rise in current export demand, which increases the price elasticity of demand $\hat{\varepsilon}_{b, t}$. In sum, the

\footnotetext{
${ }^{8}$ All the expressions have been modified to account for the fact that we have now set $\rho_{b}=0$.
} 
stronger the degree of habit formation, the more the exporter has an incentive to suppress the price markup and keep prices stable. Thus, deep habits dampen the 'pass-through' of the exchange rate fluctuation into the export price level.

Since we have additionally assumed that it is costly for the exporter to adjust prices, the response of the price level is even slower; the firm will only make small price changes to react to the movement in the markup. It is important to note that even if prices could be adjusted costlessly, export price adjustment would be slow due to the compression of the markup due to deep habits. In particular, if $h_{b}>0, \psi_{b}=0$ :

$$
\underbrace{\left(\hat{p}_{b, t}-\widehat{n m c_{t}^{*}}-\widehat{n e r}_{t}\right)}_{\hat{\mu}_{b, t}}=-\frac{\beta h_{b} \hat{\lambda}_{b, t}+\hat{\varepsilon}_{b, t}}{\eta_{c}\left(1-h_{b}\right)-\left(1-\beta h_{b}\right)} .
$$

Alternatively, in the absence of deep habits but with costly price adjustment, the change of the markup would again show up slowly in the price level. Formally, if $h_{b}=0, \psi_{b}>0$ :

$$
\underbrace{\left(\hat{p}_{b, t}-\widehat{n m} c_{t}^{*}-\widehat{n e r}_{t}\right)}_{\hat{\mu}_{b, t}}=\beta \psi_{b} \mathbb{E}_{t} \hat{\pi}_{b, t+1}-\psi_{b} \hat{\pi}_{b, t} .
$$

In the absence of deep habits, neither time-varying price elasticities nor the present value of future profits exerts a direct influence on the markup. The cost of price adjustment moderates the degree of pass-through. Finally, with neither deep habits nor costly price adjustment, the markup does not adjust, i.e. $\hat{\mu}_{b, t}=0$, so that the change in the effective nominal marginal cost brought about by the exchange rate movement will be transmitted fully to the price level instantaneously. Formally, if $h_{b}=\psi_{b}=0$ :

$$
\hat{p}_{b, t}=\widehat{n m c}_{t}^{*}+\widehat{n e r}_{t}
$$

In a nutshell, in the deep habits model, stickiness in sales quantities delays the pass-through of exchange rate fluctuations into the price level. Crucially, if habits are highly persistent, the price markup is linked tightly to current and future demand. Hence, exporters may choose to absorb the exchange rate movement into the markup instead of passing it through to the price level. This is true even when the exporters potentially can adjust prices freely, as indicated by zero or low nominal price adjustment costs. 


\subsection{Deep Habits, Sticky Prices and Exchange Rate Pass-through}

We will use numerical experiments to demonstrate the dampening influence of deep habits on the degree of exchange rate pass-through when the economy is hit by UIP shocks and monetary policy shocks. Of particular interest is a contrast of the effect of deep habits, against that of the more conventional friction used to generate incomplete exchange rate pass-through in open-economy models, i.e. stickiness in prices as embodied by the Rotemberg adjustment cost. In this simple illustration, we will assume the same degree of habit persistence for domestic and foreign sales in both countries so that $h_{a}=h_{a}^{*}=h_{b}^{*}=h_{b}=h$, and also impose the same degree of price stickiness for all sales so that $\psi_{a}=\psi_{a}^{*}=\psi_{b}^{*}=\psi_{b}=\psi$. The US is positioned as the home country and the rest of the world as the foreign country. The values we pick for the baseline parameterization of the model are in the ballpark of estimated values or calibrations for the US, available in the literature, e.g. Ravn, Schmitt-Grohé, Uribe, and Uusküla (2010b), Ravn, Schmitt-Grohé, and Uribe (2012) and Jacob and Peersman (2013). The parameter values are reported in Table 1.

The habit and price adjustment cost parameters are allowed to vary over fixed intervals. Models with deep habits are prone to indeterminacy at higher levels of habit, due to mutually reinforcing interactions between expectations of future demand and current markups (see Zubairy, 2014). The parameter ranges are hence chosen with these considerations in mind. Firstly, we choose the interval $[0,0.75]$ for the habit parameter. For the Rotemberg price adjustment cost, we set a lower bound of 1 so that the firm can change prices fairly flexibly, and the upper bound is set at 25 . In the absence of deep habits, and given the baseline values given to the elasticity of substitution $\left(\eta_{c}\right)$ between habit-adjusted demands and the discount factor $(\beta)$, these values for the Rotemberg cost parameter correspond to price durations ranging between 1.17 quarters and 2.81 quarters. ${ }^{9}$

For each combination $\{h, \psi\}$, we simulate the model using one structural shock at a time and compute the ordinary least squares (OLS) coefficient of a static regression of foreign export price inflation $\hat{\pi}_{b}$ on nominal depreciation of the home currency $\hat{\pi}^{\text {ner }}{ }^{10}$ We will label the OLS slope coefficient computed from simulated data as the 'pass-through' coefficient. The measurement of pass-through in general equilibrium is non-trivial because prices respond contemporaneously to factors other than the fluctuation in the currency's value, irrespective of the structural origin of the

\footnotetext{
${ }^{9}$ This can be achieved by abstracting from deep habits, and comparing the slopes of the Rotemberg Phillips curves with those of the Calvo-style analogs and interpreting the associated Calvo probability in terms of price duration.

${ }^{10}$ The model simulations are executed using the Matlab-based toolbox Dynare Version 4.4.3 (see Adjemian et al., 2011).
} 
Table 1: Parametrization

\begin{tabular}{llcc}
\hline \hline Parameter & & \multicolumn{2}{c}{ Value } \\
Symbol & Description & $(a)$ & $(b)$ \\
\hline & & & \\
$\psi_{a}, \psi_{a}^{*}, \psi_{b}^{*}, \psi_{b}=\psi$ & Rotemberg price adjustment cost & $1(1.17 Q), 25(2.81 Q)]$ \\
$h_{a}, h_{a}^{*}, h_{b}^{*}, h_{b}=h$ & Habit & 0 & $0.75]$ \\
$\rho_{a}, \rho_{a}^{*}, \rho_{b}^{*}, \rho_{b}$ & Persistence of habit stock & 0 & 0.90 \\
$\rho_{\text {uip }}$ & Persistence of UIP shock & 0 & 0.75 \\
$\rho_{\text {mon }}$ & Persistence of monetary policy shock & 1 & 0.50 \\
$\sigma_{\text {uip }}, \sigma_{m o n}$ & Standard deviation of shocks & 0.99 & 0.99 \\
$\beta$ & Subjective discount factor (quarterly) & 1 & 1 \\
$1 / \sigma_{c}$ & Intertemporal elasticity of substitution & 0.50 & 0.50 \\
$1 / \sigma_{n}=(1-\bar{n}) / \bar{n}$ & Frisch elasticity of labor supply & 0.987 & 0.987 \\
$\omega$ & Home-bias in consumption & 0.75 & 0.75 \\
$\xi$ & Elasticity of substitution between home and foreign goods & 6 & 6 \\
$\eta_{c}=\eta_{n}$ & Elasticity of substitution between goods/labor varieties & 0.8 & 0.8 \\
$r_{R}$ & Interest rate smoothing & 1.5 & 1.5 \\
$r_{\pi}$ & Interest rate reaction to domestic inflation & 0.1 & 0.1 \\
$r_{y}$ & Interest rate reaction to output & 25 & 25 \\
$\psi_{w}$ & Rotemberg wage adjustment cost & & \\
\hline \hline & & & \\
\hline \hline
\end{tabular}

Note: Columns (a) and (b) list the parameter values used to generate the surface plots presented in Figures 1 and 3 respectively. Other steady-state parameters are derived from the restrictions of the model. The home-bias parameter $\omega$ is set to achieve an import-intensity of 0.0375 in consumption, as observed in Table 4 of Section 4 of the National Income and Product Accounts tables published by the Bureau of Economic Analysis. The sample period we consider is 1983.Q1-2015.Q4.

cyclical disturbance. A reduction in the simple least squares correlation is only one of the several possible ways of confirming incomplete exchange rate pass-through to international prices. In the empirics presented in Section 4, we view pass-through through a different lens, i.e. based on VAR dynamics. The OLS pass-through coefficient, used in this section, provides a useful starting point.

\subsubsection{I.I.D. Shocks}

In this experiment, for simplicity, we abstract from the decaying habit stocks by setting the persistence parameters $\rho_{a}=\rho_{a}^{*}=\rho_{b}^{*}=\rho_{b}=0$ as in Section 3.1, so that the habit stock depends only on lagged consumption. Recall that the central implication of this restriction is that the dynamics of the present value of expected future profits is reduced to the relationship established in Equation (36). 
In the first graph of Panel (a) in Figure 1, we present the surface plot for the pass-through coefficient for the case in which we consider i.i.d. shocks to the UIP condition. The more interesting scenario is when we keep prices only mildly sticky by setting the Rotemberg cost low at $\psi=1$, and increase the habit parameter. Observe how the pass-through coefficient falls at higher levels of habit persistence. This pattern can be traced to the related impulse responses of the key variable in our framework: the price markup of the foreign exporter. ${ }^{11}$ In the central graph of Panel (a), we present a surface plot of the impact response of the price markup to a depreciation of the home currency triggered by a positive UIP shock, corresponding to the $\{h, \psi\}$ parameter combinations that yield the pass-through surface on the left of Panel (a). In the final graph of Panel (a), we plot the corresponding nominal exchange rate response to provide a sense of the relative strength of the movements. As we increase habit at low price stickiness, the nominal exchange rate depreciation does not change dramatically. However the decrease in the price markup is stronger at higher degrees of habit persistence which contributes to the declining degree of pass-through.

The second set of stochastic simulations uses home monetary shocks and the results are presented in Panel (b) of Figure 1. The impulse response surfaces of the markup and nominal exchange rate, shown in the middle and right graphs respectively, are triggered by negative home monetary policy shocks. These findings yields qualitatively similar results to those obtained for the UIP shocks in Panel (a). Again, when the habit parameter is increased at low degrees of price stickiness, the nominal exchange rate depreciations generated by the model are quantitatively in the same neighbourhood. In contrast, the falls in the markup are more pronounced.

\footnotetext{
${ }^{11}$ The OLS pass-through coefficient in Figure 1 is computed from artificial data using sequences of (positive as well as negative) shocks. In contrast, impulse responses are conditional on the realization of a single structural innovation and hence can only provide a flavor of how the mechanism plays out and the related OLS pass-through coefficient is affected.
} 


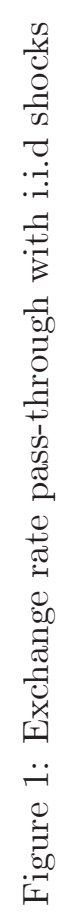
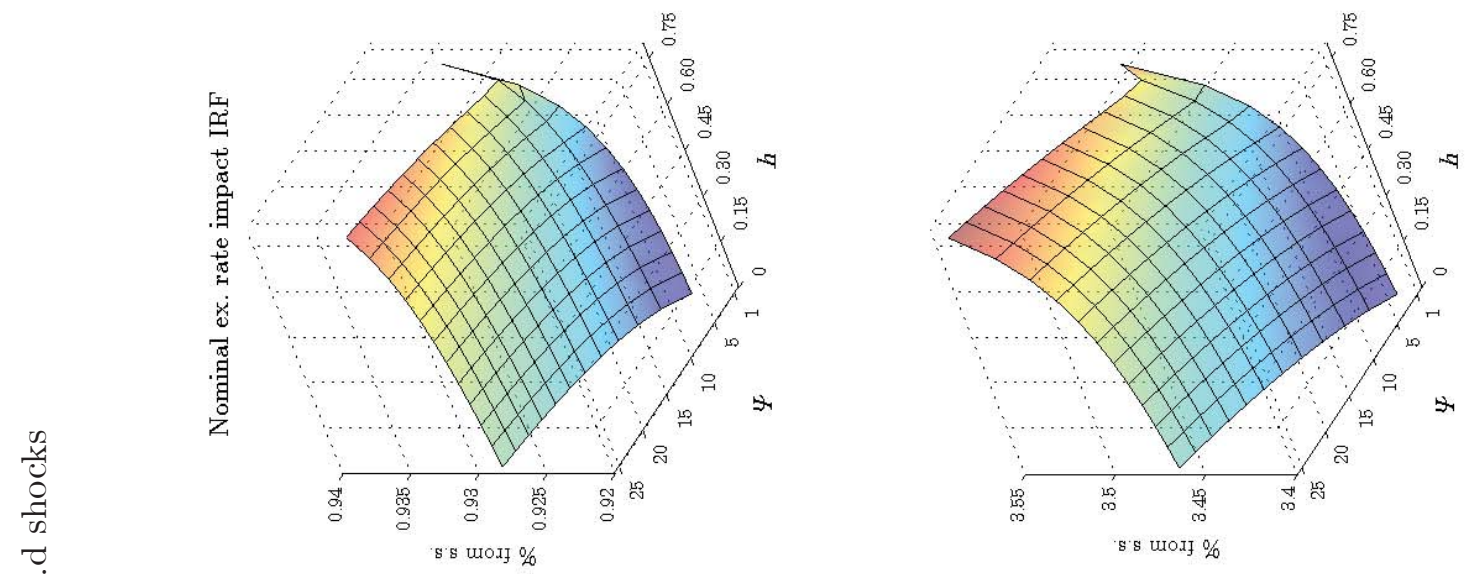

रे

구 월

की क्जि

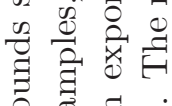
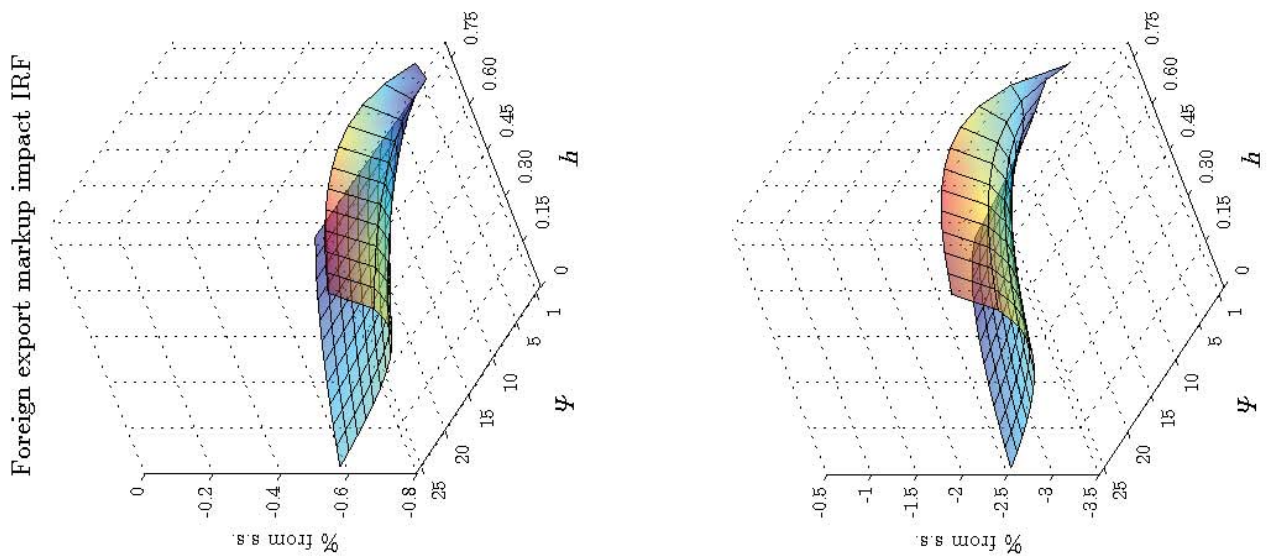

○

身

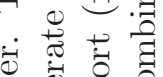

过

क्ष $8 . \exists$.

灾

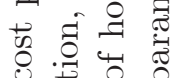

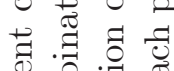

द्वै है के के

苟 0.000

它记志

.

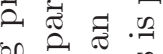

क्ञ

द्व

त्र

齐离

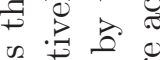

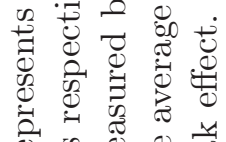

崩

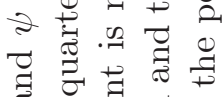
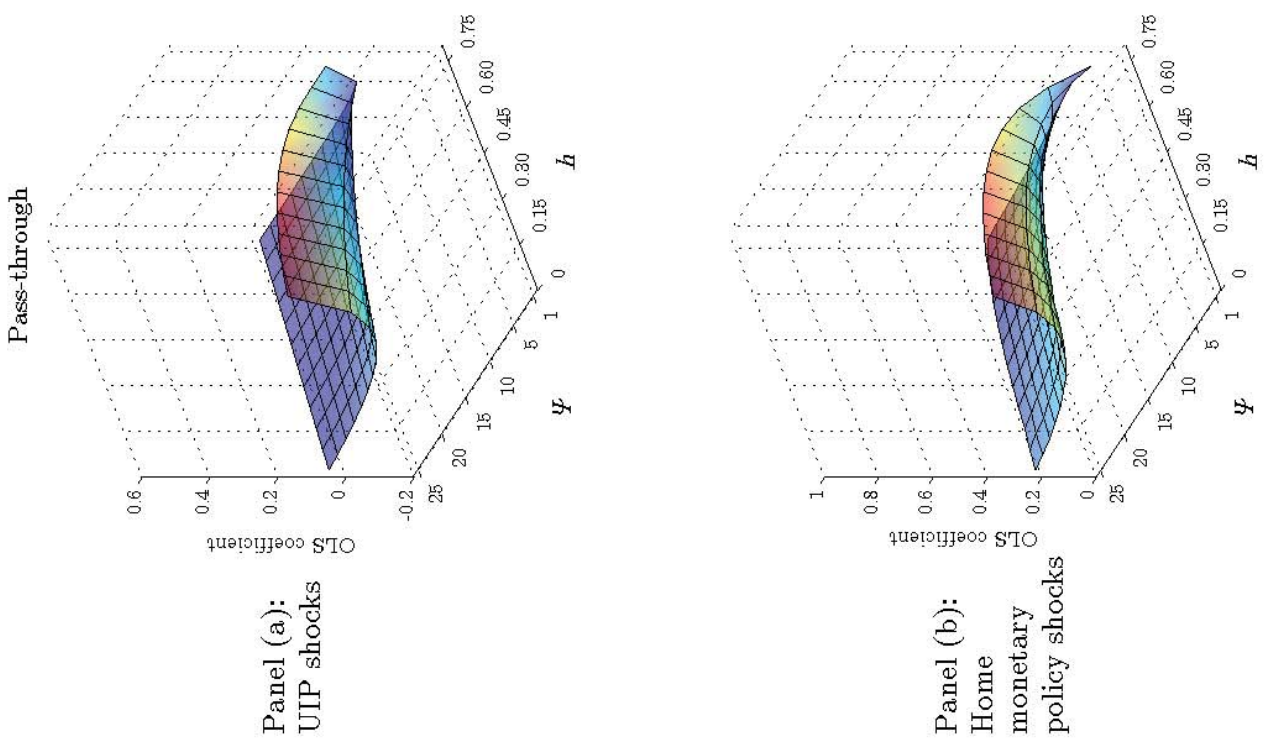

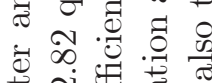

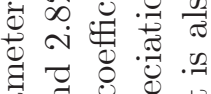

శ్ష

它

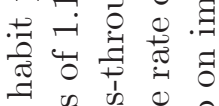

दी की 00

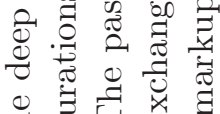

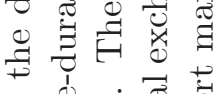

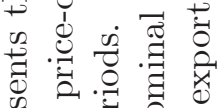

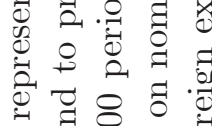

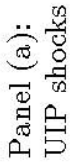

త1 $0 ี 0$.

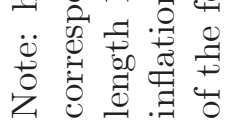


Weaker pass-through can be achieved for both structural shocks when we abstract from deep habits $(h=0)$ and raise the Rotemberg cost, the sticky price mechanism that delivers price markup adjustment in conventional open-economy New Keynesian models. It is clear from the pass-through surfaces that demand stickiness - via deep habits - and price stickiness can substitute each other in lowering exchange rate pass-through. Not surprisingly, when prices get stickier, pass-through is weakened at lower levels of habit persistence. Since markup adjustment and incomplete passthrough under sticky prices are widely understood, we will now delve deeper into how the deep habits mechanism affects the transmission of each structural shock by examining the impulse response functions.

In Figure 2, we restrict our attention to the case when the Rotemberg cost is set very low at 1 , and inspect the dynamics firstly without deep habits, and later when deep habits are prevalent. Since the peak responses are observed in the first period of impact of the shock, we will focus on this horizon. The key finding here is along the lines of the observation that the OLS pass-through coefficient from the simulations declines at higher levels of habit. The impulses triggered by both structural shocks confirm that the covariance between foreign export prices and the exchange rate is lower when deep habits are present.

In a world without deep habits, a rise in the UIP risk premium depreciates the home currency, raising foreign export prices in home currency terms, and suppressing the demand for foreign exports. Once deep habits are activated by setting $h=0.5$, the transmission of the UIP shock is magnified considerably. Since a current depreciation of the home currency implies that it is expected to appreciate in the future, the effective discount rate of the foreign exporter falls. This raises the present value of foreign export sales, exerting downward pressure on the markup (see Equation 33). ${ }^{12}$ In the presence of deep habits, foreign export volumes fall, but since they are more inertial, the decline is not as strong as in the case without habit persistence. Since the price elasticity of demand is now a positive function of demand growth, it falls on impact, exerting a positive influence on the price markup.

\footnotetext{
${ }^{12}$ In the absence of deep habits, the present value of future profits and the effective discount rate are simply auxilliary variables, and do not directly influence the firm's decisions.
} 


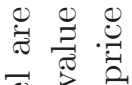

证

卷

등

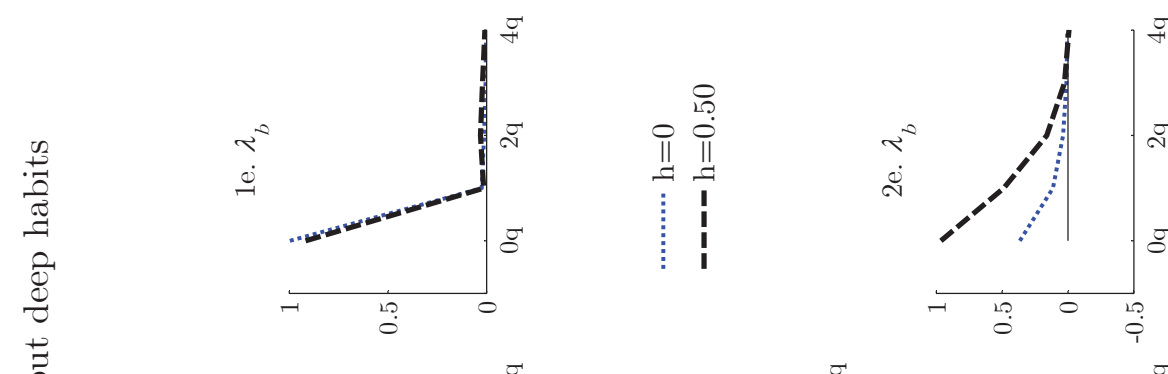

छ)

\&

范范

要

:

呵

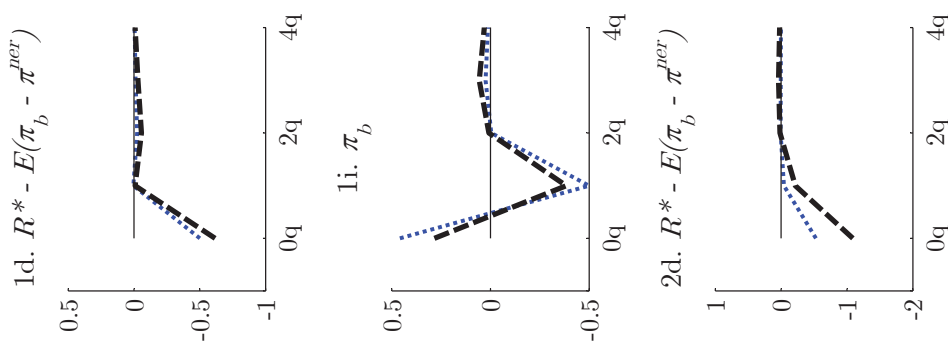

a.

.

胥

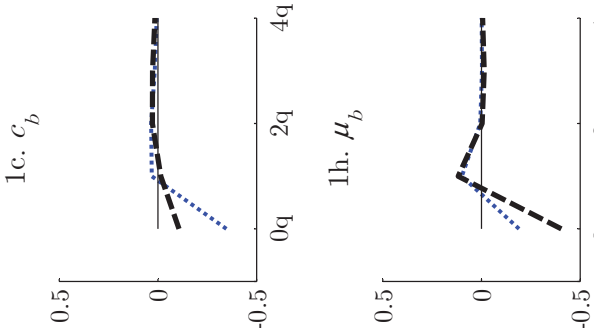

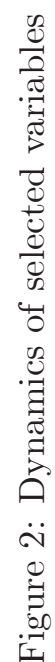
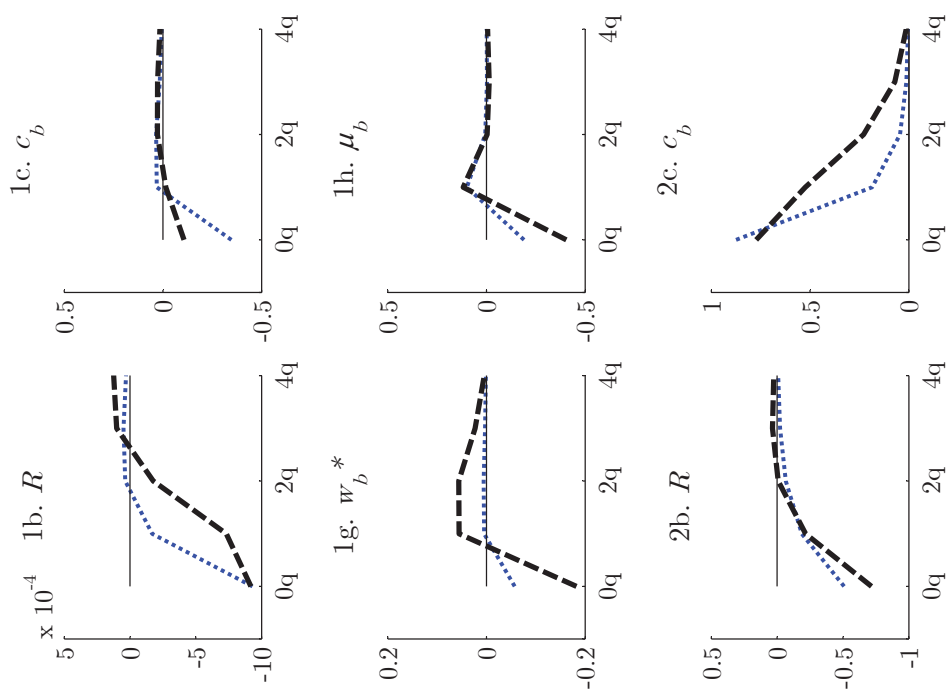

$\left.1\right|^{\text {齐 }}$

s

产
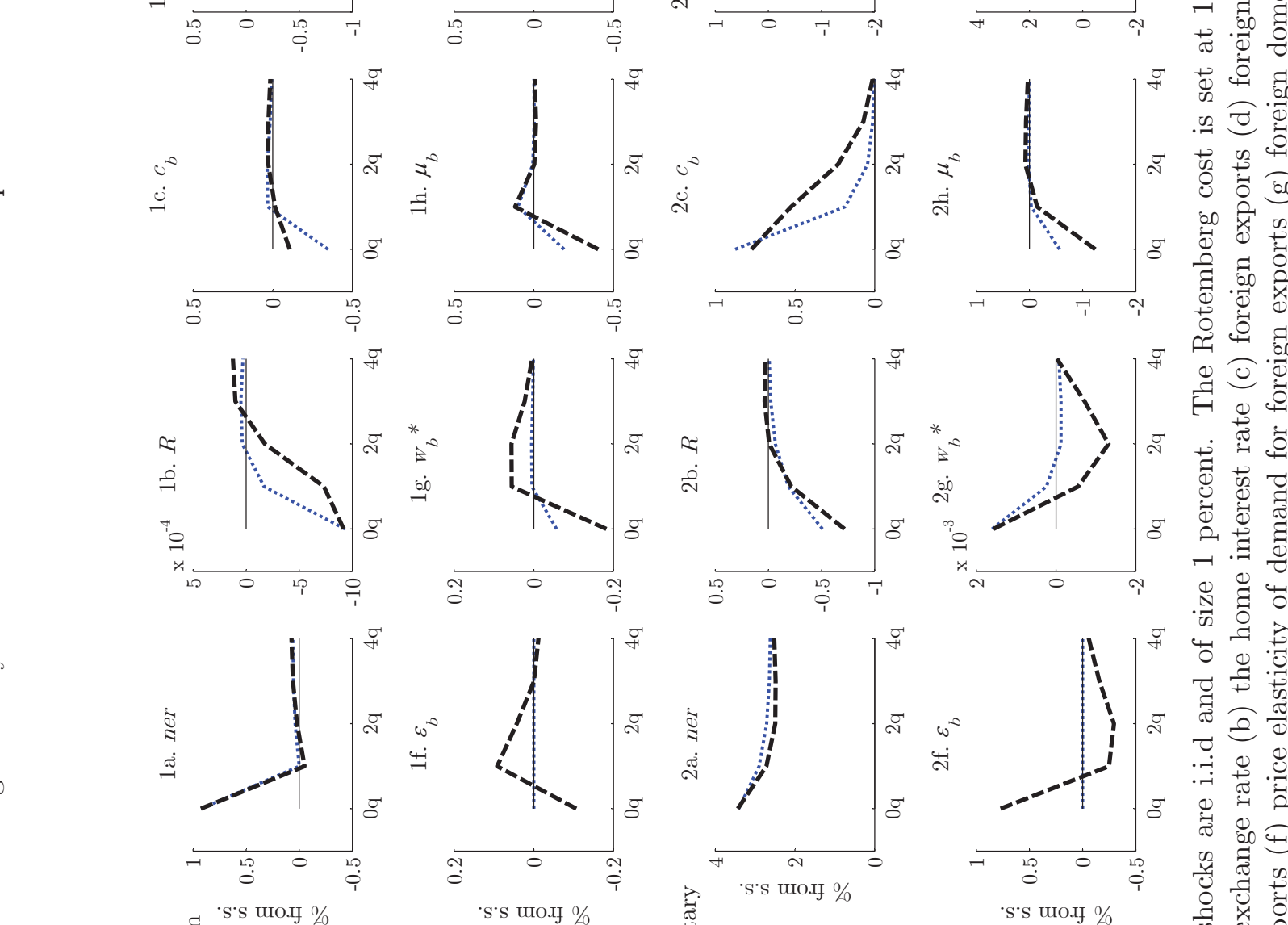

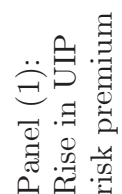

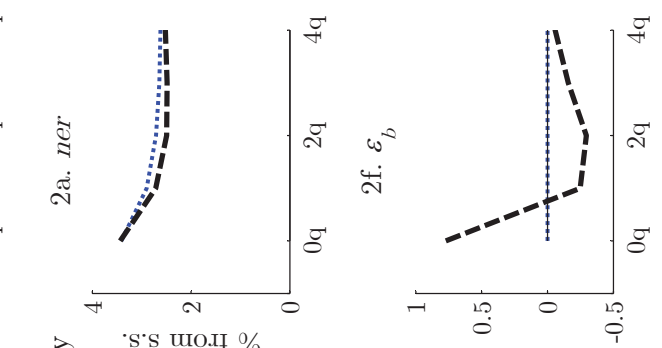

's.s uo.y \%

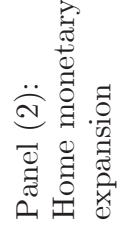

还

$\rightarrow$

总

so

등.

5 잉

군

过总

茜范

茷

离苛

嵌

ॠ

○

ฮี $\frac{\vec{\sigma}}{0}$

تُ

0

ठี 80.0

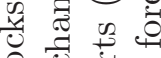

雨

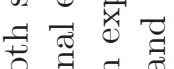

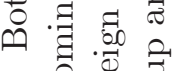

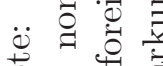

艺导苍芯 
Thus, the intertemporal and price elasticity effects of deep habits exert opposing forces on the markup in the first period. The overall effect of deep habits on the foreign export markup is a strong downward movement due to the dominance of the intertemporal effect. ${ }^{13}$ Though the nominal exchange rate movements for the models without and with deep habits are virtually identical, the price response in the latter case is more muted. Thus deep habits dampen exchange rate pass-through to foreign export prices even when prices are quite flexible.

We now alter the source of the exchange rate fluctuation. We generate a home currency depreciation by using a negative monetary policy shock in the home country. In response to the home monetary policy expansion, aggregate demand in the home economy rises, stimulating the demand for foreign exports. When deep habits are prevalent, the home currency depreciation (and the resulting expected appreciation) that is generated by the fall in the home interest rate raises the present value of foreign export profits, exerting a negative influence on the foreign export markup and prices. Concurrently, the rise in export demand also raises the price elasticity of demand which lowers the price markup. In this scenario, the intertemporal and price elasticity effects of deep habits, work in the same direction to lower the foreign export price markup. This is in contrast to the case, when the source of the exchange rate depreciation was the UIP shock, and the two effects worked in opposite directions in the period of impact.

\subsubsection{Persistent Shocks}

How does pass-through differ when the economy is hit by persistent shocks and generate more inertial movements in the nominal exchange rate? In the face of a persistent depreciation of the home currency, the cost structure of the foreign exporter firm is expected to remain unfavourable for many periods. For this reason, firms are willing to pass through a higher proportion of the currency depreciation to the consumer in the home country. The higher is the persistence of the shocks, the more inertial the habit stocks need to be, in order to increase the firm's incentive to retain demand by absorbing exchange rate fluctuations into the markup, dampening the degree of pass-through. Hence we reintroduce persistent habit stocks by setting $\rho_{a}=\rho_{a}^{*}=\rho_{b}^{*}=\rho_{b}=0.9$. This implies that the present value of expected future profits follows the more inertial path dictated by Equation (34).

\footnotetext{
${ }^{13}$ The price elasticity reverses sign and is positive in the following period as the demand for foreign exports rises to return to its long run level.
} 
We repeat the exercises from Section 3.2.1 and present the results in Figure 3. The results are qualitatively similar to those obtained in Section 3.2.1. As in the case of i.i.d. shocks, the exchange rate pass-through declines at higher levels of habit persistence, even when price stickiness is negligibly low. However, there is an important quantitative distinction between the cases of i.i.d and persistent shocks: the scale of the impulse response surfaces of the markup and nominal exchange rate presented in the middle and final columns is considerably higher than their analogs in Figure 1. UIP (in Equation 13) implies that the current level of the exchange rate is a function of the expected future path of interest rate differentials between the two regions. Persistent UIP and monetary shocks result in persistent movements in interest rate differentials, leading to higher exchange rate volatility. Consequently, the stronger movements in the currency's value result in stronger dynamics of the markup, as observed in the impulse response surface plots.

The propagation of the two shocks under deep habits is qualitatively similar to the dynamics explained in Section 3.2.1 and we omit the details of the associated impulse response functions.

\subsubsection{Home Export Price Pass-through}

What do deep habits imply for the exchange rate pass-through to home export prices or equivalently in our set-up, the import prices in the foreign country? In Figure 4, we compare the patterns of exchange rate pass-through to home import and home export prices, in the face of UIP shocks and home monetary shocks, for various combinations of the habit parameters and Rotemberg price adjustment cost. Panel (a) examines the case of UIP shocks. The first two graphs present the behavior of pass-through to home import prices, and the related dynamics of the foreign exporter's markup, earlier exhibited in Figure 1. In the third graph, we present the pass-through of the home currency depreciation to the foreign currency price of the home good. 
ב⿱
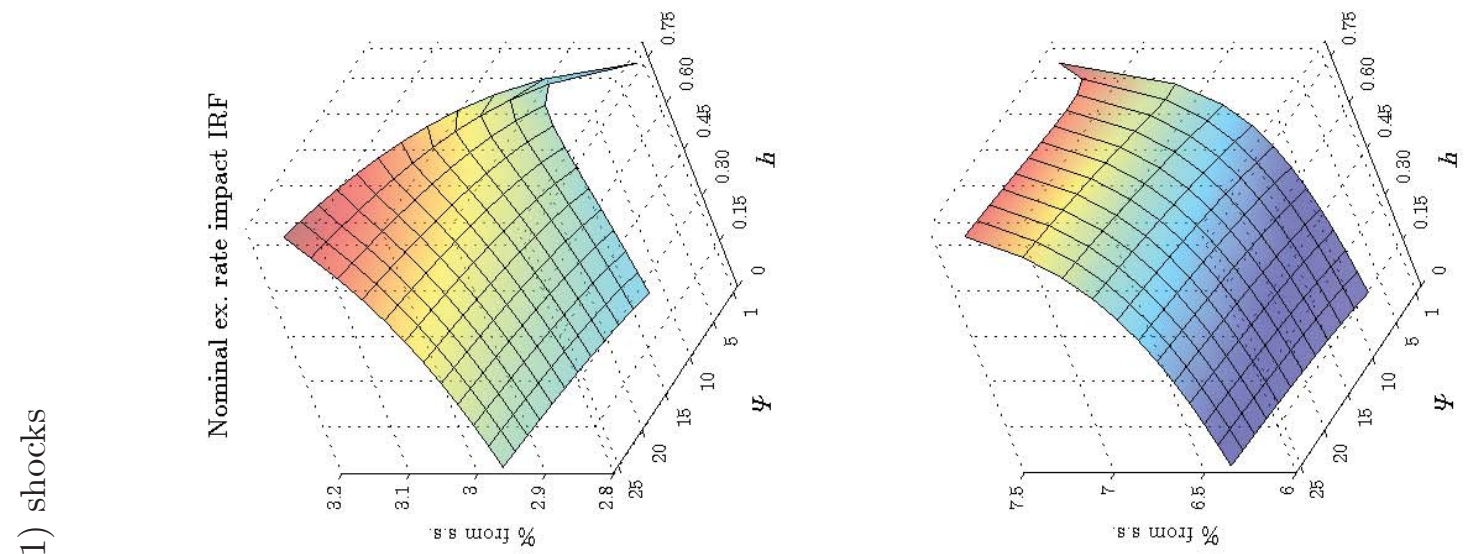

궁에

구 월

का की

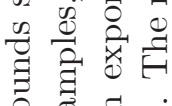
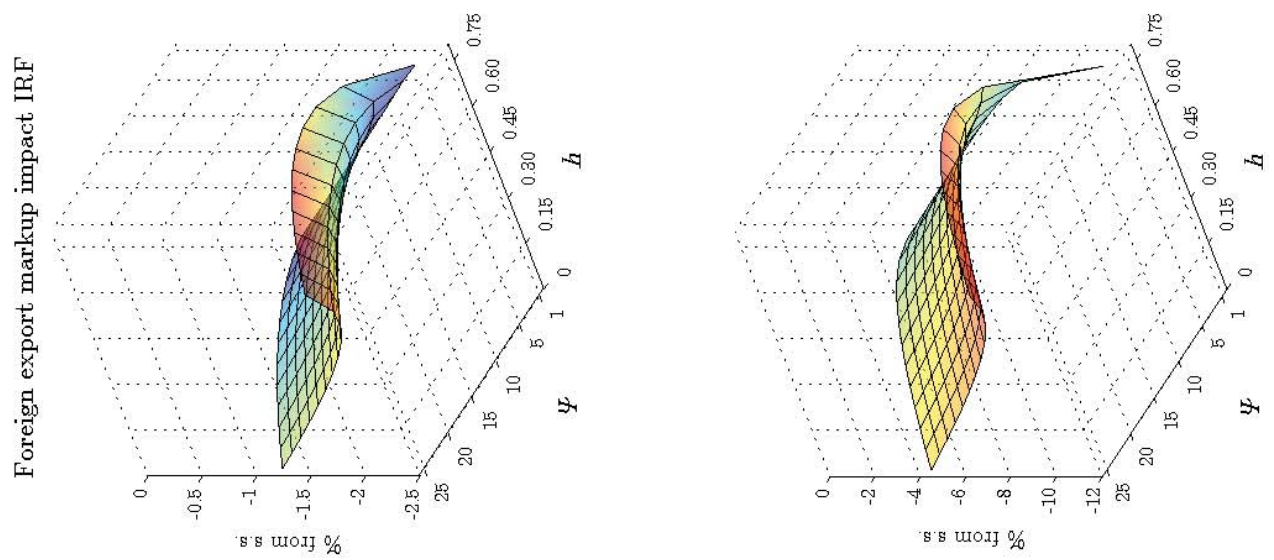

○

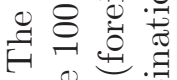

$\therefore$.

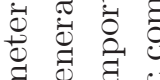

\& 8.9.

灾

范

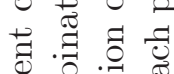

द्व है जी

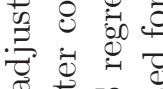

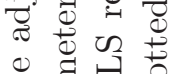

.

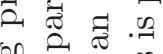

क्ञ

द्वि

त्र

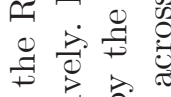

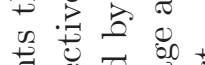

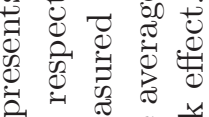

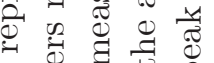

2.
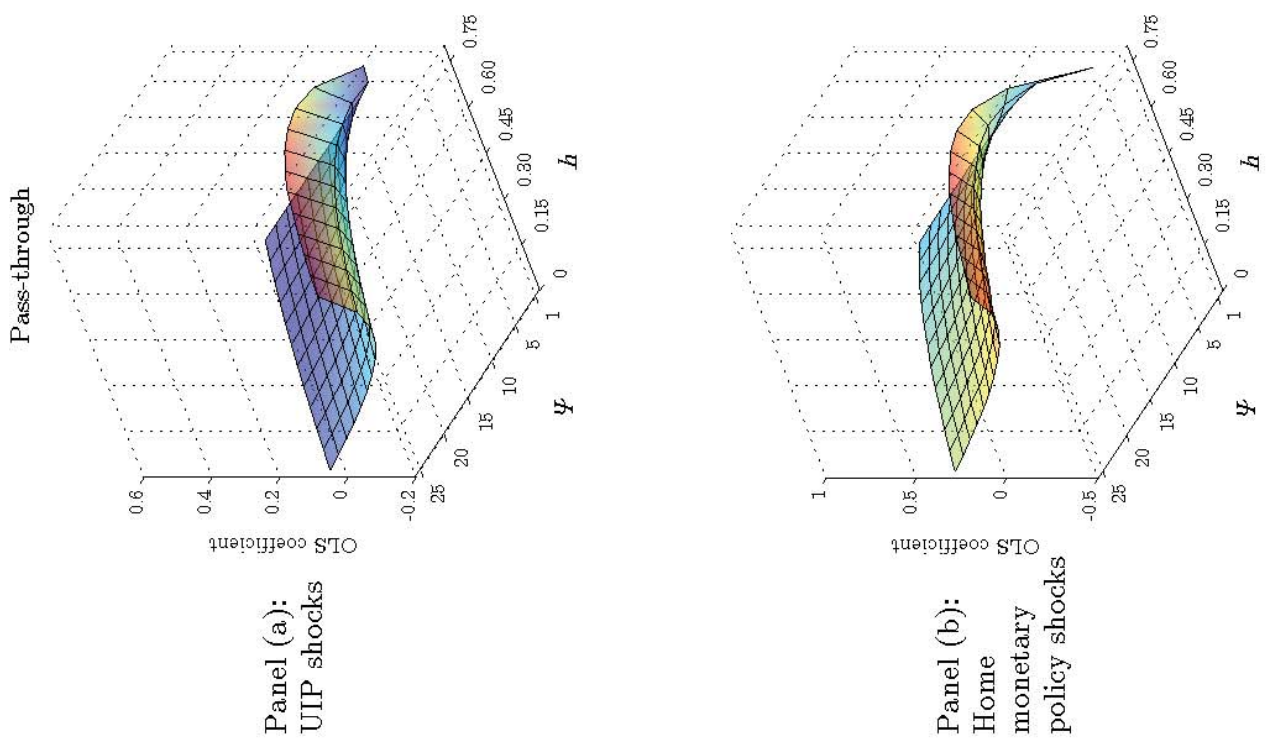

สิ

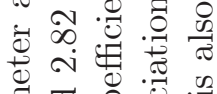

范

芯

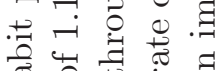

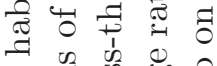

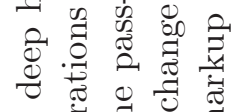

帛氙

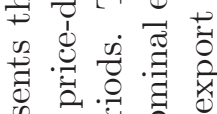

岂

党

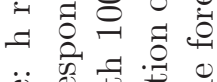

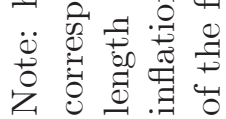


When price stickiness is very low in the economy without deep habits, the home export price falls considerably after the home currency depreciation. Once habits are activated, the home exporter has a stronger incentive to smooth profits by keeping prices stable in local currency. Therefore, the firm will increase the price markup to limit the fall in the foreign currency price of the home good. The associated home export price markup adjustment is presented in the final graph of Panel (a). Note how at extreme degrees of habit formation, the home export markup increases are fairly strong and the home export price in foreign currency even rises after a depreciation of the home currency. On the other hand, when habit is deactivated, increasing price rigidities also achieves higher home export price markups to diminish the pass-through of the currency depreciation to the foreign currency prices of the home good.

In Panel (b), we exhibit the results for the home monetary shock. In this case, the influence of deep habits on pass-through and the home export markup, at low degrees of price stickiness, is very weak. The impetus from the home monetary shock drives up the domestic demand for home and imported goods, and increasing habit persistence does not alter the home exporter's pricing behavior materially. Alternatively, if we abstract from habits, and simply increase price stickiness of home exports in foreign currency, the home export markup increases and reduces the fall of the price of the home good in the foreign market.

The relationship between export prices and exchange rates has also been studied by Drozd and Nosal (2012a), who evaluate several theoretical mechanisms that lead to pricing-to-market. In the context of this paper, one of their findings deserves careful consideration. In particular, Drozd and Nosal (2012a) find that deep habits generate a negative correlation between home export prices and the exchange rate, i.e. US export prices measured in US dollars fall when the dollar depreciates. ${ }^{14}$ This is contrary to the corresponding positive unconditional correlation found using Hodrick-Prescott filtered US data. There are substantial differences between our framework and that of Drozd and Nosal (2012a) since we use a New Keynesian model with UIP and monetary shocks, while they use an international real business cycle (RBC) model with productivity shocks. ${ }^{15}$ We do not pursue a replication of their model here, but will indicate the aspects of their modelling

\footnotetext{
${ }^{14}$ Prices of US exports and imports published by the Bureau of Economic Analysis are quoted in US dollar terms.

${ }^{15}$ Drozd and Nosal (2012a) also use a different formulation of deep habit persistence. In particular, the habitadjusted aggregate is defined in terms of the ratio $c_{t} / s_{t-1}^{h}, h<0$. This 'relative' habits specification eliminates the short-run price elasticity effect of deep habits on the markup whereas the more common 'additive' specification where habit-adjustment is made using the difference $c_{t}-h s_{t-1}, h \in[0,1)$. The latter specification yields both the intertemporal sales substitution effect as well as the price elasticity effect. See also Ravn, Schmitt-Grohé, and Uribe (2006).
} 
strategy that may explain their result.

As we have seen in this section and elsewhere in the literature, different sources of the business cycle - be it the structural interpretation or the country of origin - can have different implications for pass-through. Equally importantly, as observed in Figures 1 through 4, the strength of habit persistence and the rate of decay of the habit stock are important determinants of the degree of exchange rate pass-through, be it to import or export prices. Conditional on commonly-used parameterizatons, open-economy models generate a fall in the price of the home good and a depreciation of the home currency (rise in the exchange rate), i.e. a negative correlation, for an exogenous surge in domestic productivity which lowers production costs (see e.g. Lubik and Schorfheide, 2006). ${ }^{16}$ Drozd and Nosal (2012a), given their broader purpose of contrasting diverse models of pricing-tomarket, use a single parameter configuration for their calibration of the deep habits model, that is drawn from Ravn, Schmitt-Grohé, and Uribe (2006). The degree of habit persistence may not be strong enough in their framework to weaken the fundamental negative correlation between export prices and exchange rates, generated in productivity shock-driven international business cycle models. $^{17}$

\section{Deep Habits versus Sticky Prices: An Empirical Evaluation}

In this section, we take the model to the data. We adapt the strategy of Choudhri, Faruqee, and Hakura (2005) who estimate the responses of various prices in a panel of advanced economies to an exchange rate shock identified in a recursive VAR, and match the corresponding dynamics triggered by the shock to UIP in a suite of New Keynesian small open economy models. ${ }^{18}$ The parallel that we draw between the UIP shock and the identified empirical exchange rate shock, is imperfect; the zero restrictions imposed in the VAR identification are unlikely to be satisfied by our general equilibrium environment. However, as a horserace between the two competing model

\footnotetext{
${ }^{16}$ An exception is the negative transmission of productivity shocks detailed in Corsetti, Dedola, and Leduc (2008b). Under extreme home-bias and high complementarity between home and foreign goods, the wealth effect after a positive home productivity shock of near-unit root persistence can lead to an appreciation of the home terms of trade.

${ }^{17}$ In other experiments (not presented in this paper) using home productivity shocks at very low degrees of price stickiness, increasing habit persistence diminishes exchange rate pass-through to home export prices. However, even for higher levels of habit persistence, the depreciation of the home currency is accompanied by a fall in the home export price, i.e. the conditional correlation continues to be negative. Hence the productivity-shock driven version of our model does not generate the positive unconditional correlation observed in US data by Drozd and Nosal (2012a). These additional results are available on request.

${ }^{18} \mathrm{~A}$ vast empirical literature on exchange rate pass-through uses single equation models (see e.g. Burstein and Gopinath, 2014), that do not allow dynamic feedback between the variables of interest and hence are less suitable empirical benchmarks for our DSGE model.
} 
frictions - deep habits and local currency price stickiness - in dampening the conditional exchange rate pass-through observed in the VAR, the matching exercise is instructive.

\subsection{The Identified Exchange Rate Shock}

We focus on the cyclical dynamics of three US time series: the price deflator of imported consumption goods $\left(p^{m}\right)$, the price deflator of consumption goods $\left(p^{c}\right)$ and the nominal effective exchange rate (neer) of the US dollar that covers exchange rates with a broad basket of trading partners. ${ }^{19}$ We select consumption-based prices since the theoretical model abstracts from physical capital and government expenditures. The data spans 1983.Q1 to 2015.Q4 and the variables are presented in their natural logarithms. Formally, the VAR is represented as:

$$
A\left[\begin{array}{l}
\Delta \text { neer }_{t} \\
\Delta p_{t}^{m} \\
\Delta p_{t}^{c}
\end{array}\right]=B(L)\left[\begin{array}{l}
\Delta \text { neer }_{t-1} \\
\Delta p_{t-1}^{m} \\
\Delta p_{t-1}^{c}
\end{array}\right]+\epsilon_{t}
$$

The parameter matrix $A$ is of size 3 by 3 and factor $B(L)$ denotes a lag polynomial with $L$ denoting the lag operator. Finally $\epsilon_{t}$ is the vector of residuals. We include linear trends in the model and use 2 lags.

We identify the exchange rate shock by placing the nominal effective exchange rate first in the system of variables. The matrix $A$ has zero elements above the diagonal. A consequence of this constraint is that while the exchange rate can affect price indices instantaneously, the price indices do not have a contemporaneous effect on the exchange rate. The identification is equivalent to a Cholesky decomposition when the exchange rate is placed first in the system and is essentially a generalization of the single equation approach used by Burstein and Gopinath (2014). In order to concentrate on the dynamics of import and consumption prices, we use a much smaller VAR than Choudhri, Faruqee, and Hakura (2005).

\footnotetext{
${ }^{19}$ The nominal effective exchange rate is taken from the FRED2 database of the Federal Reserve Bank of St.Louis (mnemonic TWEXBMTH). The remaining series are drawn from the National Economic Accounts of the Bureau of Economic Analysis. The import price of consumption goods (mnemonic B652RG3) is from Table 4.2.4 while the deflator for personal consumption expenditures (mnemonic DPCERG3) is from Table 1.1.4. The choice of the aggregate consumption import price implies that an aggregate of US trade partners constitutes the second region in our model. The unavailability of bilateral trade price data eliminates the possibility of using a single currency zone, e.g. the Euro-area, as the foreign country.
} 


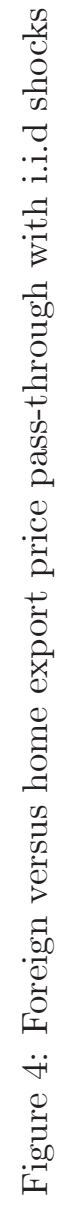
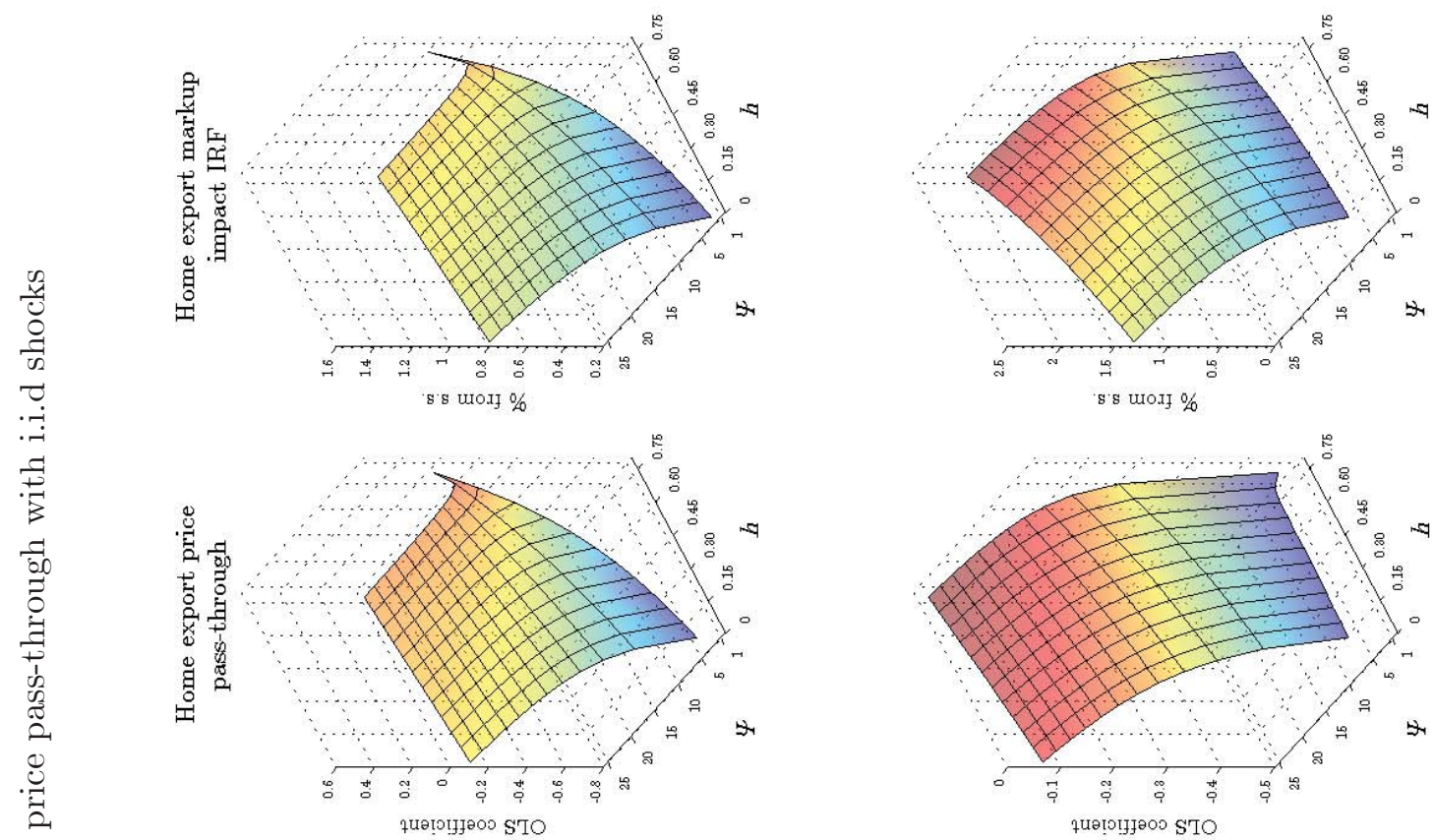

2 प.

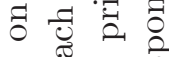

跑

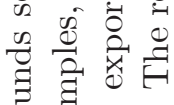

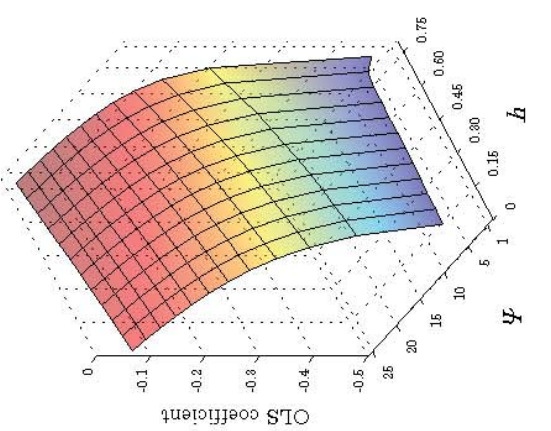

8 ॠ

里 8

. 눈

过苞

สิ

芯艿寻

䓎

류

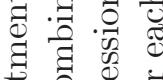

苟

: ت્0.

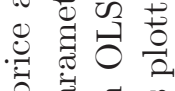

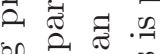

क्ष

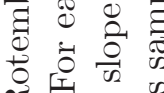

ح1
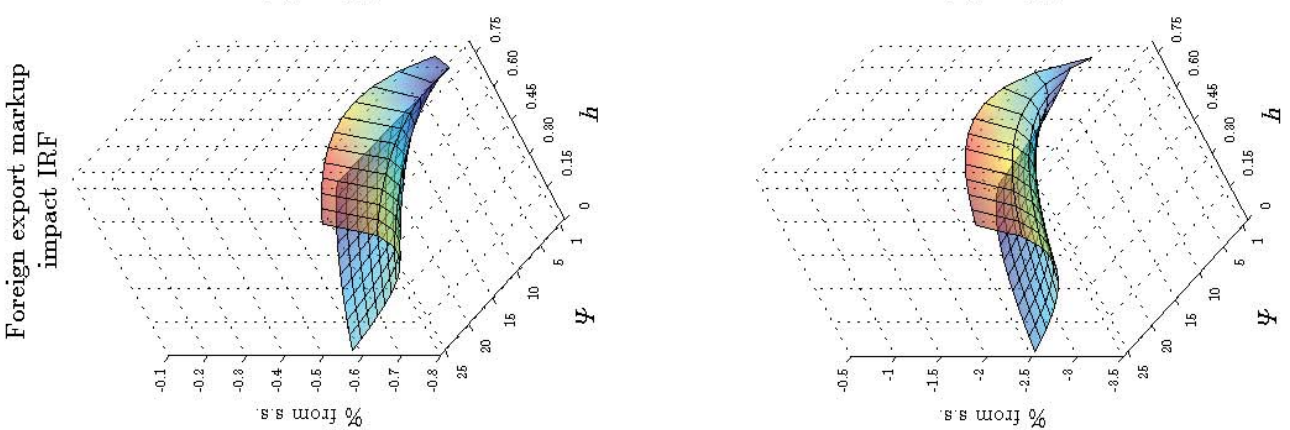

吾击

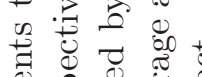

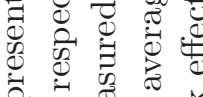

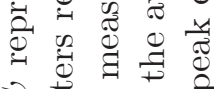

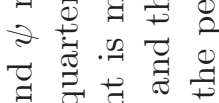

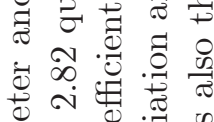
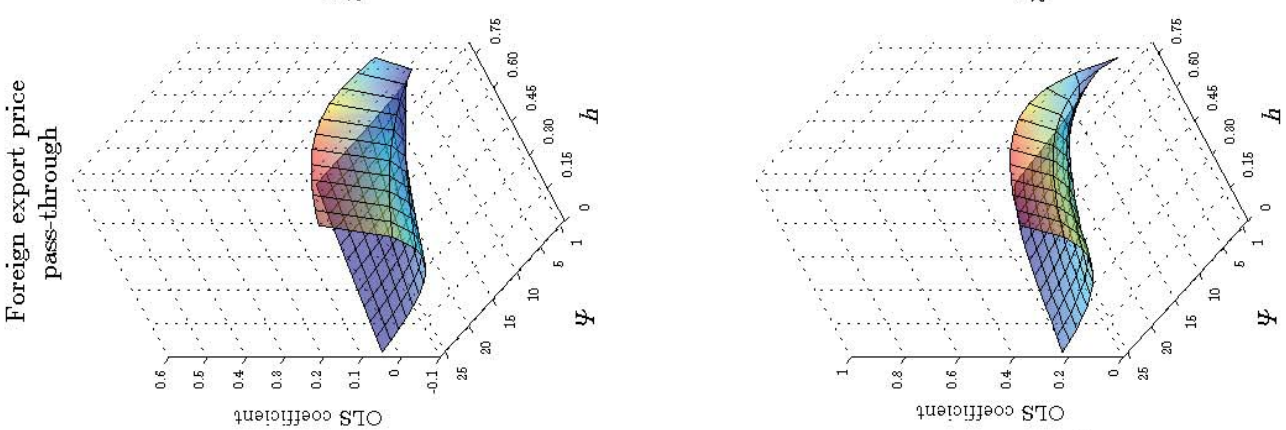

용.

䒕

ڤึ.

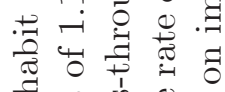

दी की 0

进.

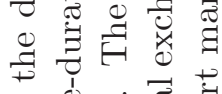

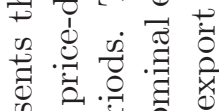

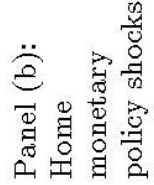

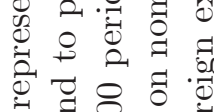

- 107000

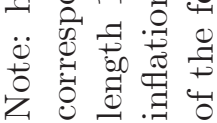


To understand the influence of deep habits in the determination of exchange rate pass-through, we will now estimate two model variants by matching their dynamics to the VAR benchmark. While the first variant features deep habits, the second abstracts from the friction. The two variants of the theoretical model will share a common trigger of the business cycle, the shock to UIP given in Equation (13) .

\subsection{Model Variants and Estimation Methodology}

To prepare the two model variants for estimation, we alter the baseline model in two dimensions. As a first step, we introduce price indexation in the firm's optimization program so that lagged inflation influences the Phillips curves. Specifically, the US import Phillips curve in the model variant with deep habits is now given as:

$$
\hat{\pi}_{b, t}=\frac{\iota_{b}}{1+\beta \iota_{b}} \hat{\pi}_{b, t-1}+\frac{\beta}{1+\beta \iota_{b}} \mathbb{E}_{t} \hat{\pi}_{b, t+1}-\frac{\left(\hat{\nu}_{b, t}+\hat{x}_{b, t}-\hat{c}_{b, t}\right)}{\psi_{b}\left(1+\beta \iota_{b}\right)}
$$

where $\iota_{b} \in[0,1]$ represents the degree of indexation. Secondly, in the version of the model without deep habits, we retain price indexation but also introduce standard superficial habit formation, so that habits only affect the demand-side of the economy as in conventional models and is eliminated from the firm's profit-maximisation program. We will refer to the latter variant of the model with superficial habits and price indexation as the pure sticky price model. The US import Phillips curve in the pure sticky price model is expressed as:

$$
\hat{\pi}_{b, t}=\frac{\iota_{b}}{1+\beta \iota_{b}} \hat{\pi}_{b, t-1}+\frac{\beta}{1+\beta \iota_{b}} \mathbb{E}_{t} \hat{\pi}_{b, t+1}-\frac{\hat{\mu}_{b, t}}{\psi_{b}\left(1+\beta \iota_{b}\right)} .
$$

In the two model variants, a subset $\Theta$ of the model parameters will be estimated while the rest, represented by the vector $\alpha$, take the baseline values given in Table 1. We depart from our simple baseline parametrization in Section 3 and allow the estimated parameters to span a wider range of values, further easing the estimation. We relax the constraint that all deep habit parameters are identical and allow the habit persistence for domestic sales and export sales to be different. However, to simplify the solution of the modified steady-state, the habit parameters are still restricted to be the same across countries, i.e. $h_{a}=h_{b}^{*}$ and $h_{a}^{*}=h_{b}$. We approach the estimation of decay parameters for the habit stocks similarly. On the other hand, in the pure sticky price model, we estimate the superficial habit parameter and the associated persistence of the habit stock. The other 
important set of estimated coefficients involves the parameters that govern price stickiness. We allow the Rotemberg price adjustment costs and price indexation coefficients to differ for domestic and export sales in both countries, leading to a total of 8 estimated price stickiness parameters. In addition, we estimate parameters related to wage stickiness and the UIP shock process.

The estimation procedure involves assigning values for the structural parameters in vector $\Theta$ to minimize the distance between the empirical pass-through impulse response functions (IRFvar) and the corresponding theoretical pass-through impulse response functions (IRF theory) implied by the theoretical model(s). Since we focus on a forecast horizon of 16 periods for the dynamics of US import and consumer prices relative to that of the exchange rate, the relevant vector is of order $32 \times 1$. Formally, the estimated parameter vector $\widehat{\Theta}$ is chosen to minimise the loss function:

$$
\widehat{\Theta}=\min _{\Theta}\left(I R F^{\text {var }}-I R F^{\text {theory }}(\Theta \mid \alpha)\right) \mathbb{W}^{-1}\left(I R F^{\text {var }}-I R F^{\text {theory }}(\Theta \mid \alpha)\right)
$$

The weighting matrix $\mathbb{W}$ is the $32 \times 32$ diagonal variance matrix estimated from the bootstrapped empirical exchange rate pass-through. The weighting matrix places a larger weight on VAR impulses that are estimated precisely and a smaller weight on VAR impulses that are estimated imprecisely. The estimate of the variance-covariance matrix $\Sigma_{\widehat{\Theta}}$ of the estimated parameters $\widehat{\Theta}$ is given by $\Sigma_{\widehat{\Theta}}=\left(J_{\widehat{\Theta}}^{\prime} \mathbb{W}^{-1} J_{\widehat{\Theta}}\right)^{-1}$ where $J_{\widehat{\Theta}}$ denotes the Jacobian of the theoretical impulse response functions with respect to the estimated parameters. ${ }^{20}$

\subsection{Estimation Results}

We present the estimation results in Figure 5 and Table 2. In contrast to the calibration exercise in Section 3, our empirical measure of pass-through is dynamic and conditional on the effects of a single realization of the shock. In particular, as in Choudhri, Faruqee, and Hakura (2005), pass-through is computed by dividing the cumulated impulse responses of changes in prices by the cumulated impulse responses of the changes in the exchange rate. Figure 5 presents the effects of the identified exchange rate shock on pass-through, up to a forecast horizon of 16 quarters. The median response is indicated by a solid black line while the shaded gray area represents the non-centred $90 \%$ confidence bands based on 5000 replications obtained from non-parametric bootstrapping.

The exchange rate pass-through to US import prices increases steadily from $15 \%$ on impact of

\footnotetext{
${ }^{20}$ For the empirics, the model is solved using the method of undetermined coefficients as in Uhlig (1999), and the matching exercise is implemented in Matlab.
} 
the shock to a maximum of $37 \%$ after about 10 quarters. As one would expect in a relatively closed economy as the US, the exchange rate pass-through to consumer prices is much lower: on impact of the shock, pass-through reaches $5 \%$ and levels off at just above $8 \%$ after 10 quarters. In the underlying impulse responses (not presented), a 1\% increase in the exchange rate (depreciation of the US dollar) is very persistent, staying at around 1\% after 16 quarters after the shock implying that the underlying impulse responses for prices exhibit similar qualitative patterns. Our dynamic pass-through estimates for the US conditional on the exchange rate shock, are in the ballpark of the analogous results for other countries available in Choudhri, Faruqee, and Hakura (2005) for a panel of non-US G7 economies and in Faruqee (2006) for the Euro-area.

In the top and bottom panels of Figure 5, we compare the dynamics obtained from the two model variants. The dynamics from the deep habits model are indicated by red circular markers while those from the pure sticky price model are indicated by dashed blue lines. Both model variants are able to fit the pass-through fairly well, with their implied dynamics mostly lying in the estimated empirical $90 \%$ confidence intervals. An exception is the case of the pure sticky price model, where the consumption deflator pass-through mildly breaches the VAR confidence bands in the initial periods following the impact of the shock.

The estimated structural parameters that underpin the dynamics in Figure 5, are presented in Table 2. The first column presents the parameter estimates and associated standard deviations of the deep habits model while the second column does the same for the pure sticky price model. In the discussion, we will mainly examine the differences in the habit and price stickiness parameters across the model variants.

The main insight from the estimation results is that the deep habits model can fit the passthroughs without relying heavily on price stickiness. The estimated Rotemberg price adjustment cost parameters are very low, ranging between 0.01 for home export sales to about 5.55 for foreign domestic sales. These cost parameters, if interpreted in terms of the price-duration scale associated with Calvo (1983), imply price changes that on average occur between 1.002 and 1.66 quarters respectively. Price indexations are at zero with the exception of the domestic export price indexing, for which the Rotemberg cost is estimated very close to zero. At negligibly low price stickiness, deep habits play a pivotal role in matching the pass-through dynamics. The habit parameters for domestic and export sales are estimated just below the 0.75 mark. Both the habit stocks are extremely persistent, with the related $\mathrm{AR}(1)$ coefficients approaching unity, which implies that the 
stocks do not depreciate over time.

These estimates are consistent with the previous US data-based estimates of the deep habits parameter by matching government spending shocks by Ravn, Schmitt-Grohé, and Uribe (2012) who find a deep habit parameter above 0.5 and the habit stock persistence close to one. The results are also similar to the estimates of the deep habit parameter found by matching monetary policy shocks by Ravn, Schmitt-Grohé, Uribe, and Uusküla (2010b) who find a habit parameter of 0.85. Wage stickiness also appears to play a supporting role in matching the pass-through; the estimate for the adjustment cost approaching 27, which corresponds to an average wage duration of 2.9 quarters. All parameters in the deep habits model are estimated with extreme precision.

The parameter estimates that emerge from the pure sticky price model are starkly different. This variant of the model requires the home domestic good adjustment cost to be about 24,749 which corresponds to an average price spell of about 100 quarters. The foreign export adjustment cost to be equal to 85 which implies a price change every 4.7 quarters. The home export price stickiness parameter is also extremely high, exceeding 1,121,879 indicating a price duration that exceeds 1000 quarters. Wages become fully flexible in this model variant, the cost of wage-adjustment approaching zero. The superficial habit parameter estimated at a very high value at about 0.998 , but there appears to be no persistence in the corresponding habit stock. A notable feature in the parameter estimates in the pure sticky price model is the extreme large standard errors in many cases. Not surprisingly, the pass-through dynamics predicted by the model are not very sensitive to changes in the parameters at the extremely high price adjustment cost values.

The relatively poor fit of the pure sticky price model is confirmed by the much higher value of the corresponding quadratic loss function, presented in the last row of Table 2. Clearly, the deep habits model matches the SVAR dynamics better, quite in line with the observation that the dynamics from the deep habits model were closer to the empirical analogs in Figure 5.

The qualitative results are preserved in several robustness checks that we conducted; the deep habits model continues to match the pass-through dynamics with very little dependence on nominal price stickiness. These checks include (a) constraining all the habit parameters to be the same (b) estimating the pure sticky price model without employing superficial habits (which even worsens fit) (c) fixing the persistence of the habit-stock at 0.9876, the value estimated by Ravn, Schmitt-Grohé, and Uribe (2012), and (d) matching the SVAR dynamics for a shorter horizon. These additional results are available on request. 


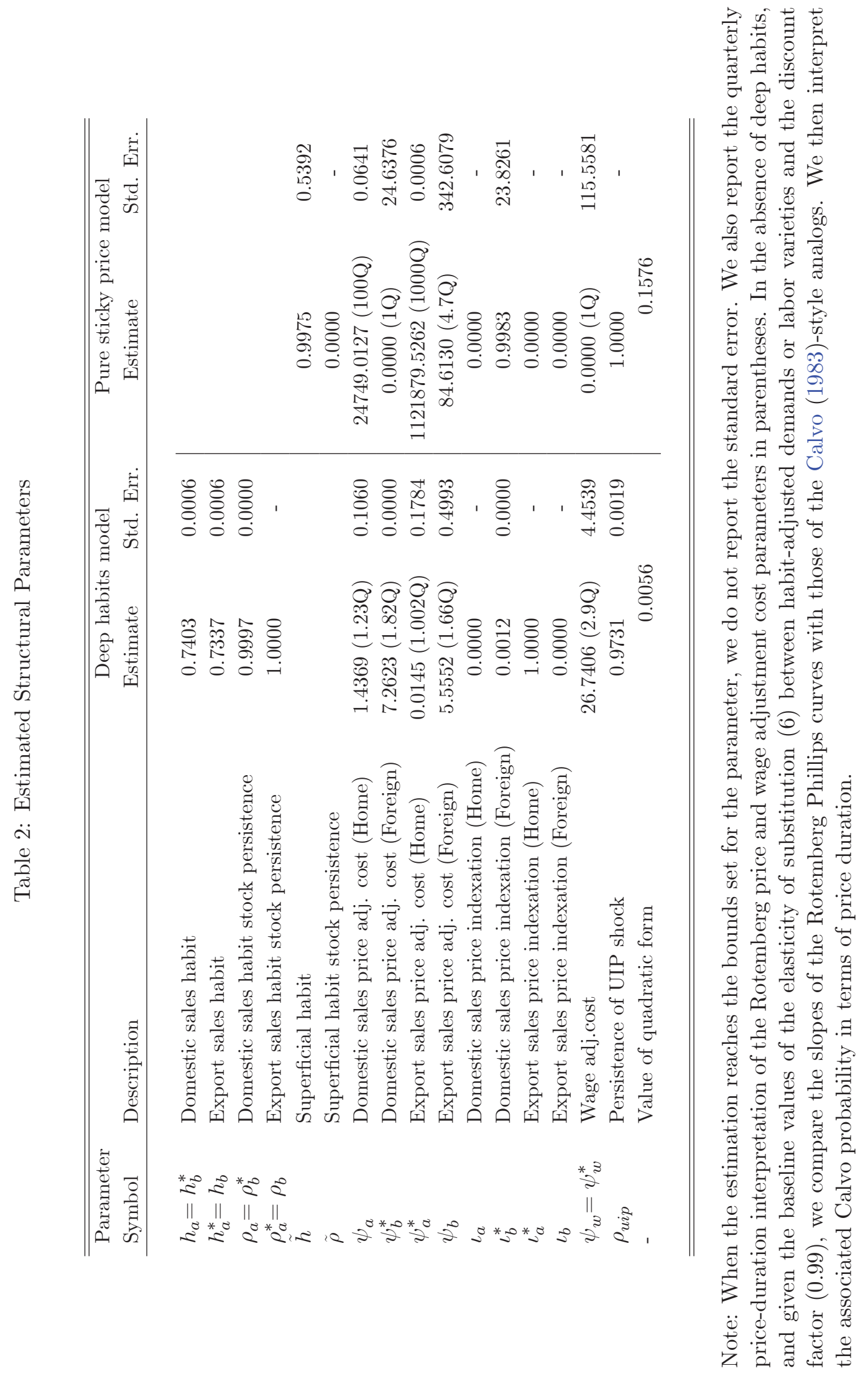



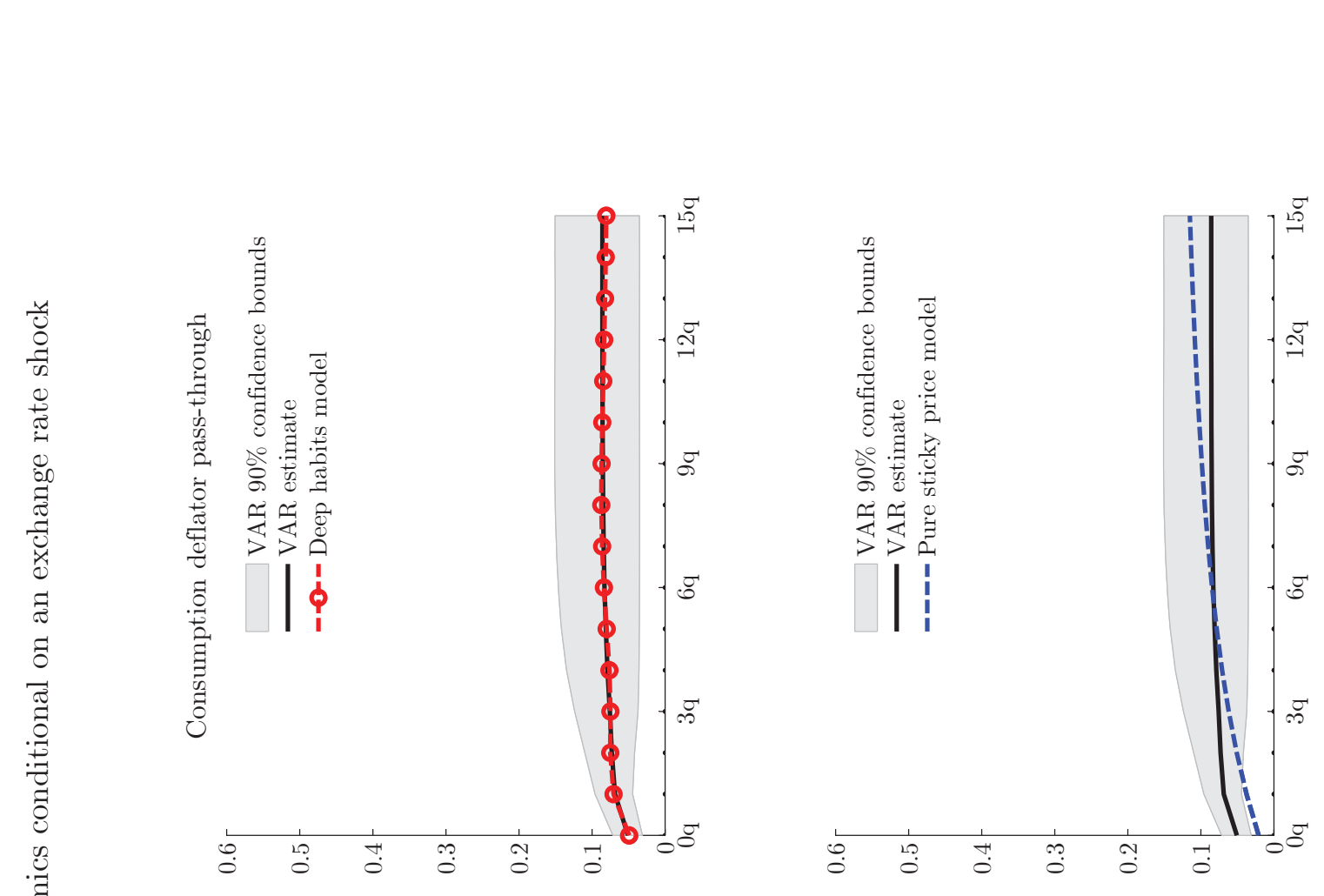

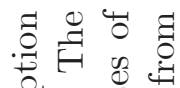
छี

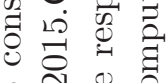

ת

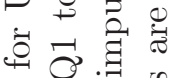

कृ

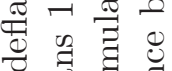
४ $\left.\tilde{\pi}_{\pi}\right]$

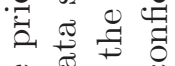
당 500

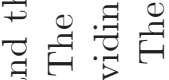
ช

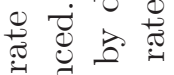

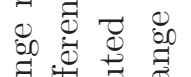
䨠 0.

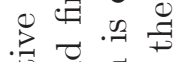
苞

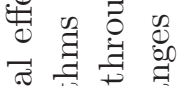
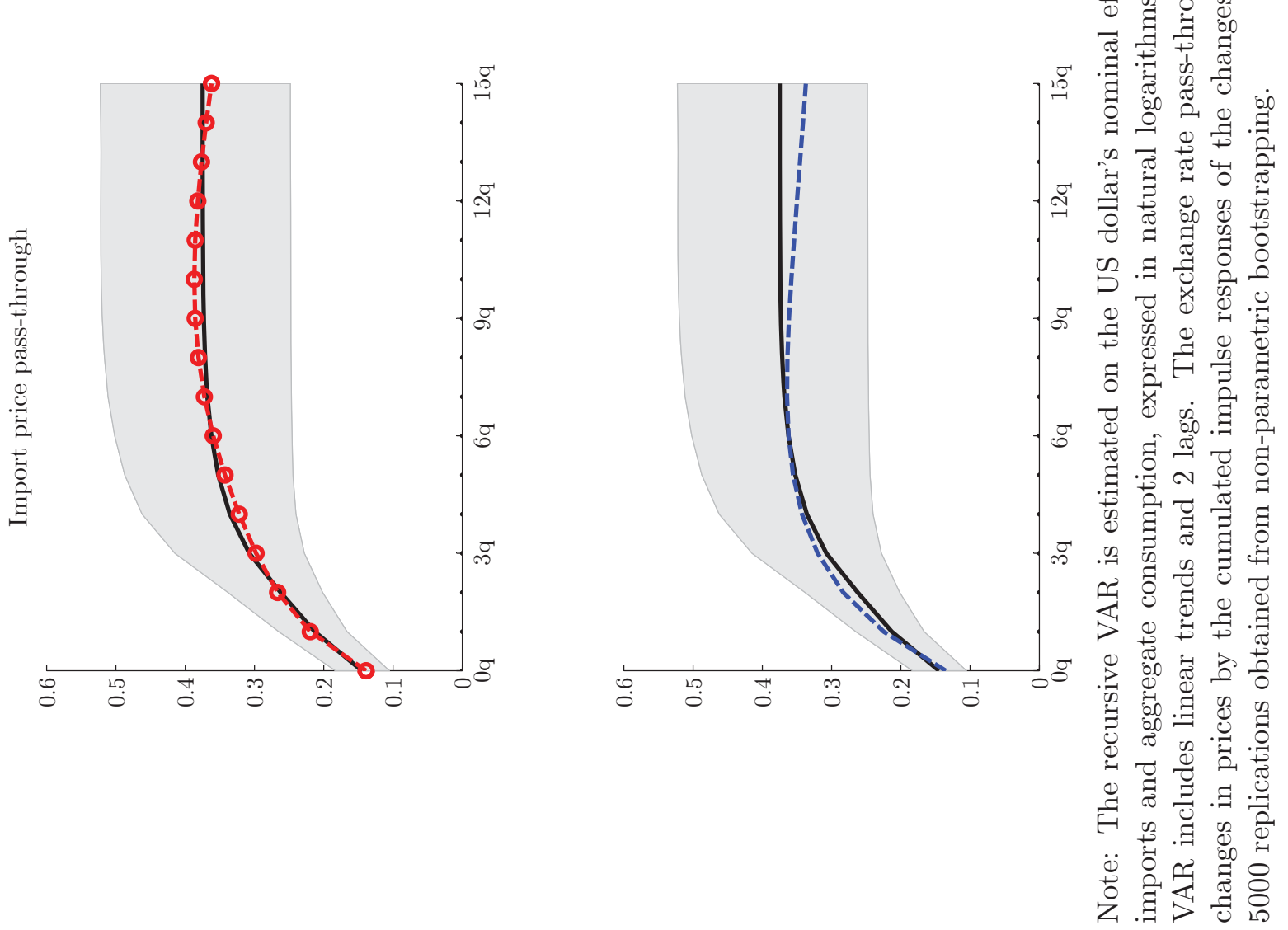


\section{Conclusion}

Stickiness in demand can dampen the pass-through of exchange rate fluctuations into international prices, even when stickiness in nominal prices is fairly low. We demonstrate this by embedding preferences featuring good-specific or deep habits into an otherwise standard two-country New Keynesian model. In an economy with deep habits, firms can maximize expected discounted profits by adjusting sales over time: stronger habit persistence implies a higher positive covariance between current sales of the firm with future sales, and consequently with future profits. Furthermore, the price elasticity of demand is a positive function of demand growth. Against this backdrop, we generate depreciations of the currency in which the exporter's price is denominated, using random deviations from uncovered interest parity and shocks to monetary policy. The deep habits mechanism operates through two channels to generate the suppression of the export price markup, lowering exchange rate pass-through. Specifically, if the shock raises either the current value of expected future profits or the price elasticity of demand, the currency depreciation is partially absorbed into the price markup and not fully passed through to international prices. The directions of the cyclical movements in these two variables are dictated by the structural origin of the disturbance. For the baseline calibration, the intertemporal and price elasticity effects exert opposing forces on the markup for the UIP shock while the two effects work in the same direction for the monetary policy shock. Deep habits and sticky prices complement each other to reduce pass-through in the case of both shocks: with increasing price stickiness, pass-through is reduced by a milder degree of habit persistence and on the other hand, stronger habits weakens pass-through even when prices are quite flexible.

We compare the empirical performance of a pure sticky price model with that of the New Keynesian model with deep habits by formally matching the dynamics triggered by a UIP shock in the two variants, to those generated by an exchange rate shock identified in a VAR. The deep habits model fits the dynamics better than the competing sticky price model. Crucially, the deep habits model is able to replicate the pass-through dynamics well even with a fairly low estimate for the price adjustment cost parameter. However, once we abstract from deep habits, the pure sticky price model requires the adjustment cost to reach extremely high, empirically implausible values, to match the VAR dynamics. 


\section{References}

Adjemian, S., H. Bastani, F. Karamé, M. Juillard, J. Maih, F. Mihoubi, G. Perendia, J. Pfeifer, M. Ratto, and S. Villemot (2011), Dynare: Reference Manual Version 4, Dynare working papers, CEPREMAP.

Adolfson, M., S. Laséen, J. Lindé, and M. Villani (2007), Bayesian Estimation of an OpenEconomy DSGE Model with Incomplete Pass-through, Journal of International Economics, $72(2), 481-511$.

Alessandria, G. (2009), Consumer search, price disperson, and international relative price fluctuations, International Economic Review, 50(3), 803-829.

Alessandria, G., J. P. Kaboski, and V. Midrigan (2010), Inventories, Lumpy Trade, and Large Devaluations, American Economic Review, 100(5), 2304-39.

Atkeson, A. and A. Burstein (2008), Pricing-to-market, trade costs, and international relative prices, American Economic Review, 98(5), 1998-2031.

Bergin, P. R. (2006), How well can the New Open Economy Macroeconomics explain the Exchange Rate and Current Account?, Journal of International Money and Finance, 25(5), 675-701.

Burstein, A. and G. Gopinath (2014), International Prices and Exchange Rates, vol. 4, 391451, Elsevier.

Calvo, G. A. (1983), Staggered Prices in a Utility-maximizing Framework, Journal of Monetary Economics, 12(3), 383-398.

Choudhri, E. U., H. Faruqee, and D. S. Hakura (2005), Explaining the exchange rate passthrough in different prices, Journal of International Economics, 65, 349-374.

Corsetti, G. and L. Dedola (2005), A macroeconomic model of international price discrimination, Journal of International Economics, 67(1), 129-155.

Corsetti, G., L. Dedola, and S. Leduc (2008a), High Exchange Rate Volatility and Low Passthrough, Journal of Monetary Economics, 55(6), 1113-1128.

Corsetti, G., L. Dedola, and S. Leduc (2008b), International Risk Sharing and the Transmission of Productivity Shocks, Review of Economic Studies, 75(2), 443-473.

Devereux, M. B. and C. Engel (2002), Exchange Rate Pass-through, Exchange Rate Volatility, and Exchange Rate Disconnect, Journal of Monetary Economics, 49(5), 913-940.

Devereux, M. B. and J. Yetman (2010), Price adjustment and exchange rate pass-through, Journal of International Money and Finance, 29(1), 181-200.

Drozd, L. A. and J. B. Nosal (2012a), Pricing to market in business cycle models, 2012 Meeting Papers 1108, Society for Economic Dynamics.

Drozd, L. A. and J. B. Nosal (2012b), Understanding international prices: Customers as capital, American Economic Review, 102(1), 364-95.

Erceg, C., D. Henderson, and A. Levin (2000), Optimal Monetary Policy with Staggered Wage and Price Contracts, Journal of Monetary Economics, 46(2), 281-313. 
Faruqee, H. (2006), Exchange rate pass-through in the euro area, IMF staff papers, 53(1), 63-88.

Gopinath, G., O. Itskhoki, and R. Rigobon (2010), Currency Choice and Exchange Rate Pass-through, American Economic Review, 100(1), 304-36.

Gust, C., S. Leduc, and R. Vigfusson (2010), Trade integration, competition, and the decline in exchange-rate pass-through, Journal of Monetary Economics, 57(3), 309-324.

Jacob, P. and G. Peersman (2013), Dissecting the Dynamics of the US Trade Balance in an Estimated Equilibrium Model, Journal of International Economics, 90(2), 302-315.

Lubik, T. and F. Schorfheide (2006), A Bayesian Look at the New Open Economy Macroeconomics, in: NBER Macroeconomics Annual 2005, Volume 20, NBER Chapters, 313-382, National Bureau of Economic Research, Inc.

Lubik, T. A. and W. L. Teo (2014), Deep habits in the new keynesian phillips curve, Journal of Money, Credit and Banking, 46(1), 79-114.

McCallum, B. T. and E. Nelson (1999), Nominal Income Targeting in an Open-economy Optimizing Model, Journal of Monetary Economics, 43(3), 553-578.

Monacelli, T. (2005), Monetary Policy in a Low Pass-through Environment, Journal of Money, Credit and Banking, 37(6), 1047-1066.

Rabanal, P. and V. Tuesta (2010), Euro-Dollar Real Exchange Rate Dynamics in an Estimated Two-Country Model: An Assessment, Journal of Economic Dynamics and Control, 34(4), 780797.

Ravn, M. O., S. Schmitt-Grohé, and M. Uribe (2006), Deep Habits, Review of Economic Studies, 73(1), 195-218.

Ravn, M. O., S. Schmitt-Grohé, and M. Uribe (2007), Pricing to Habits and the Law of One Price, American Economic Review, 97(2), 232-238.

Ravn, M. O., S. Schmitt-Grohé, and M. Uribe (2010a), Incomplete Cost Pass-through Under Deep Habits, Review of Economic Dynamics, 13(2), 317-332.

Ravn, M. O., S. Schmitt-Grohé, and M. Uribe (2012), Consumption, government spending, and the real exchange rate, Journal of Monetary Economics, 59(3), 215 - 234.

Ravn, M. O., S. Schmitt-Grohé, M. Uribe, and L. Uusküla (2010b), Deep Habits and the Dynamic Effects of Monetary Policy Shocks, Journal of the Japanese and International Economies, 24(2), 236-258.

Rotemberg, J. (1982), Monopolistic Price Adjustment and Aggregate Output, Review of Economic Studies, 49(4), 517-31.

Smets, F. and R. Wouters (2002), Openness, Imperfect Exchange Rate Pass-through and Monetary Policy, Journal of Monetary Economics, 49(5), 947-981.

Uhlig, H. (1999), A toolkit for analyzing nonlinear dynamic stochastic models easily, in: R. Marimon and A. Scott (eds.), Computational Methods for the Study of Dynamic Economies, 30-61, Oxford University Press.

Zubairy, S. (2014), Interest Rate Rules And Equilibrium Stability Under Deep Habits, Macroeconomic Dynamics, 18(01), 23-40. 